\title{
Modeling ultrafine particle growth at a pine forest site influenced by anthropogenic pollution during BEACHON-RoMBAS 2011
}

\author{
Y. Y. Cui ${ }^{1}$, A. Hodzic ${ }^{2}$, J. N. Smith ${ }^{2,3}$, J. Ortega ${ }^{2}$, J. Brioude ${ }^{4,5}$, H. Matsui ${ }^{6}$, E. J. T. Levin ${ }^{7}$, A. Turnipseed ${ }^{2}$, \\ P. Winkler ${ }^{2,8}$, and B. de Foy ${ }^{1}$ \\ ${ }^{1}$ Department of Earth and Atmospheric Sciences, Saint Louis University, MO, USA \\ ${ }^{2}$ National Center for Atmospheric Research, Atmospheric Chemistry Division, P.O. Box 3000, Boulder, CO 80307, USA \\ ${ }^{3}$ Department of Applied Physics, University of Eastern Finland, Kuopio, Finland \\ ${ }^{4}$ Chemical Sciences Division, Earth System Research Laboratory, NOAA, Boulder, CO 80305, USA \\ ${ }^{5}$ Cooperative Institute for Research in Environmental Sciences, University of Colorado, Boulder, CO 80309, USA \\ ${ }^{6}$ Japan Agency for Marine-Earth Science and Technology, Kanagawa, Japan \\ ${ }^{7}$ Department of Atmospheric Science, Colorado State University, Fort Collins, CO, USA \\ ${ }^{8}$ Faculty of Physics, University of Vienna, Boltzmanngasse 5, 1090 Vienna, Austria
}

Correspondence to: A. Hodzic (alma@ucar.edu)

Received: 6 February 2014 - Published in Atmos. Chem. Phys. Discuss.: 4 March 2014

Revised: 11 August 2014 - Accepted: 9 September 2014 - Published: 20 October 2014

\begin{abstract}
Formation and growth of ultrafine particles is crudely represented in chemistry-climate models, contributing to uncertainties in aerosol composition, size distribution, and aerosol effects on cloud condensation nuclei $(\mathrm{CCN})$ concentrations. Measurements of ultrafine particles, their precursor gases, and meteorological parameters were performed in a ponderosa pine forest in the Colorado Front Range in JulyAugust 2011, and were analyzed to study processes leading to small particle burst events (PBEs) which were characterized by an increase in the number concentrations of ultrafine 4-30 nm diameter size particles. These measurements suggest that PBEs were associated with the arrival at the site of anthropogenic pollution plumes midday to early afternoon. During PBEs, number concentrations of 4-30 nm diameter particles typically exceeded $10^{4} \mathrm{~cm}^{-3}$, and these elevated concentrations coincided with increased $\mathrm{SO}_{2}$ and monoterpene concentrations, and led to a factor-of- 2 increase in $\mathrm{CCN}$ concentrations at $0.5 \%$ supersaturation. The PBEs were simulated using the regional WRF-Chem model, which was extended to account for ultrafine particle sizes starting at $1 \mathrm{~nm}$ in diameter, to include an empirical activation nucleation scheme in the planetary boundary layer, and to explicitly simulate the subsequent growth of Aitken particles (10-100 nm) by condensation of organic and inorganic vapors. The updated model reasonably captured measured aerosol number
\end{abstract}

concentrations and size distribution during PBEs, as well as ground-level CCN concentrations. Model results suggest that sulfuric acid originating from anthropogenic $\mathrm{SO}_{2}$ triggered PBEs, and that the condensation of monoterpene oxidation products onto freshly nucleated particles contributes to their growth. The simulated growth rate of $\sim 3.4 \mathrm{~nm} \mathrm{~h}^{-1}$ for 4 $40 \mathrm{~nm}$ diameter particles was comparable to the measured average value of $2.3 \mathrm{~nm} \mathrm{~h}^{-1}$. Results also suggest that the presence of PBEs tends to modify the composition of sub$20 \mathrm{~nm}$ diameter particles, leading to a higher mass fraction of sulfate aerosols. Sensitivity simulations suggest that the representation of nucleation processes in the model largely influences the predicted number concentrations and thus $\mathrm{CCN}$ concentrations. We estimate that nucleation contributes $67 \%$ of surface $\mathrm{CCN}$ at $0.5 \%$ supersaturation in this pine forest environment.

\section{Introduction}

Submicron particles reduce atmospheric visibility, impact human health, and influence climate by radiative forcing and by modifying the number of cloud condensation nuclei (CCN) (Somers et al., 2004; Laaksonen et al., 2005). To accurately predict these effects, precise estimates of the 
aerosol size distribution are required (Adams and Seinfeld, 2002; Dusek et al., 2010) in addition to the typically reported mass concentrations. Modeling aerosol size distributions is challenging due to uncertainties involved in the formation and growth of new particles (Pierce et al., 2011). A new particle formation event is the result of complex processes where molecular clusters $(1-2 \mathrm{~nm})$ are created by nucleation of gases that can subsequently grow into detectablesized particles depending on the outcome of two competing processes: condensation of semi-volatile organic and inorganic gases and coagulation to preexisting particles (Kulmala, 2003; Kerminen and Kulmala, 2002; McMurry et al., 2005). Studies have shown that nucleated clusters originate from sulfuric acid, water, ammonia, and organic compounds (Zhang et al., 2004; Sipilä et al., 2010; Kulmala et al., 2013; Kirkby et al., 2011); however the mechanisms of formation are still being developed. Ultrafine aerosols can become active $\mathrm{CCN}$ with changes in their size distribution and chemical properties and thus can have an impact on cloud properties, precipitation and regional climate (McFiggans et al., 2006 Rosenfeld et al., 2008). Kerminen et al. (2005) estimated that cloud droplets originated from new particle formation over the boreal forests in Finland are associated with a radiative cooling of $0.2-0.9 \mathrm{Wm}^{-2}$.

Predicting nucleation events and their effect on $\mathrm{CCN}$ concentrations is challenging, and the results largely depend on the selected nucleation scheme and the environmental conditions. Previous studies have reported that binary and ternary homogeneous nucleation schemes (nucleation of $\mathrm{H}_{2} \mathrm{SO}_{4}$ ) that are commonly used in 3-D climate models tend to underestimate nucleation rates and particle number concentrations by orders of magnitude, especially within the boundary layer (e.g., Kulmala et al., 2006; Young et al., 2008). Merikanto et al. (2009) used activation nucleation (AN) parameterization (Kulmala et al., 2006) in the boundary layer and binary homogeneous nucleation in the free troposphere, and estimated that nucleation contributes $45 \%$ of global mean CCN $(0.2 \%$ super saturation (SS)), of which $35 \%$ can be attributed to the flux of nucleated particles from the free troposphere and $10 \%$ from the boundary layer. Matsui et al. (2011) used a similar approach within a regional model in the polluted urban environment of Beijing, and predicted that new particle formation increased CCN concentrations at high $(>0.2 \%)$ supersaturations, and decreased $\mathrm{CCN}$ at low $(<0.1 \%)$ supersaturation. Given the uncertainties in available parameterizations, Pierce and Adams (2009) compared several nucleation schemes that spanned 6 orders of magnitude in globally averaged nucleation rates, and estimated that the average tropospheric CCN concentrations varied by less than $17 \%$ in the troposphere, and by $12 \%$ within the boundary layer at low $(0.2 \%)$ supersaturations. Although the global CCN predictions were only moderately sensitive to the choice of nucleation scheme, the presence of nucleation was found to be crucial for predicting CCN. Luo and Yu (2011) used the ionmediated nucleation scheme and predicted that new particle formation accounted for $80 \%$ of CCN $(0.4 \%$ SS) in most parts of the eastern United States.

Aerosol nucleation and subsequent growth have been observed in various environments including urban areas (Matsui et al., 2011), coastal regions (O'Dowd et al., 2002), and rural and forest environments (Kulmala et al., 2001; Levin et al., 2012; Pierce et al., 2012). In the current study, we define the term "small particle burst event" (PBE) to describe the appearance and growth of particles that are larger than $3 \mathrm{~nm}$ in diameter in contrast with typical nucleation events that include particles between 1 and $3 \mathrm{~nm}$. Here PBEs refer to both nucleation-mode particles $(<10 \mathrm{~nm})$ and Aitken-mode particles $(10-100 \mathrm{~nm})$. Particle formation events, whether arising from local nucleation of new particles or PBE-type events, have frequently been observed in clean forest air masses, for example in Finland (Kulmala et al., 2001). However it is unclear if the same types of processes are occurring in forests influenced by anthropogenic pollution because urban plumes contain gases that both contribute to the onset of nucleation and also contain sufficient concentrations of preexisting particles onto which condensable gases can partition instead of nucleating. Understanding how forest environments respond to the inflow of pollutants from the nearby cities is of great scientific interest as populations at the forest-urban interfaces are increasing. Jung et al. (2013) showed that the inflow of urban air masses could favor the initiation of the burst of nucleation-mode particles in an isoprene-rich deciduous forest in northern Japan. However, studies in other types of forests, such as terpene-rich forests, are less conclusive. As part of the Bio-hydro-atmosphere interactions of Energy, Aerosols, Carbon, $\mathrm{H}_{2} \mathrm{O}$, Organics \& Nitrogen (BEACHON, Ortega et al., 2014) project, there are long-term measurements of trace gases, aerosols and meteorological parameters at the Manitou Experimental Forest Observatory (MEFO). This site is located within a semi-arid ponderosa pine forest in the Colorado Front Range. It is representative of an urban-rural interface and provides a unique opportunity to study aerosol formation in a monoterpene-rich environment that is periodically influenced by the inflow of anthropogenic pollution from Denver and Colorado Springs (DiGangi et al., 2012; Fry et al., 2013; Ortega et al., 2014). The PBEs observed at the site during the summer months were found to coincide with an increase in CCN concentrations at high supersaturations (Levin et al., 2012), but the origin of the ultrafine particle formation events was not investigated.

In this paper, we use data from the BEACHON Rocky Mountain Biogenic Aerosol Study (RoMBAS) intensive measurement period (25 July to 25 August 2011) to investigate the origin of ultrafine aerosol formation and growth events, and to model their characteristics using the regional Weather Research and Forecasting model with chemistry (WRF-Chem, Grell et al., 2005; Fast et al., 2006). More specifically, we will use measurements and model simulations to (1) characterize the connection between anthropogenic pollution and the occurrence of PBEs, (2) test the 
ability of the WRF-Chem model to predict the levels of ultrafine particles during PBE episodes at the site, and (3) quantify their influences on $\mathrm{CCN}$ concentrations. As biogenic emissions dominate the volatile organic compound concentrations at this site (Kaser et al., 2013; Ortega et al., 2014), their effects on the growth of newly nucleated particles will also be investigated. The WRF-Chem model is particularly well suited for this study as it simultaneously treats biogenic emissions, chemistry and CCN.

\section{Measurement site and circulation patterns during the campaign}

The Manitou Experimental Forest Observatory (MEFO; $39.1006^{\circ} \mathrm{N}, 105.0942^{\circ} \mathrm{W}$ ) is located in the Front Range of the Colorado Rockies at $\sim 2300 \mathrm{~m}$ elevation in a subalpine forest dominated by ponderosa pine (Fig. 1). It is located $40 \mathrm{~km}$ northwest of Colorado Springs and $72 \mathrm{~km}$ southwest of Denver. The site is frequently influenced by polluted air from the Front Range urban areas. Previous studies at MEFO have indicated that monoterpenes and 2methyl-3-butene-2-ol (MBO) are the dominant component of volatile organic compound (VOC) emissions during the daytime (Kim et al., 2010; Kaser et al., 2013; Ortega et al., 2014). Concentrations of anthropogenic pollutants (e.g $\mathrm{NO}_{\mathrm{x}}$, $\mathrm{SO}_{2}$, benzene) observed at the site are variable and driven by synoptic and local meteorological conditions. Meteorological observations from the meteorological tower at MEFO have been used to analyze the diurnal variations of wind speeds and wind directions during both the BEACHONROCS (2010) and BEACHON-RoMBAS (2011) campaigns (Ortega et al., 2014). During daytime in the summer, easterly upslope flows are often observed at MEFO with wind speeds of 2-3 $\mathrm{m} \mathrm{s}^{-1}$, whereas during nighttime strong southwesterly drainage flows dominate with typical wind speeds around 3-5 $\mathrm{m} \mathrm{s}^{-1}$. PBEs at MEFO almost always occur during midday, and it is suspected that these events are related to transport from the urban areas to the east.

\section{Measurements and modeling framework}

\subsection{Data sets}

Measurements from several instruments are used in this study to characterize PBEs during BEACHONRoMBAS 2011. Particle size distributions from $4 \mathrm{~nm}$ to $3 \mu \mathrm{m}$ were measured on a 5-minute cycle. The method consists of two scanning mobility particle sizers (SMPSs) that measure particles from 4 to $30 \mathrm{~nm}$ and from 30 to $300 \mathrm{~nm}$, and an optical particle counter that measures particles from $200 \mathrm{~nm}$ to $3 \mu \mathrm{m}$. The final data set is composed of the superposition of the three different measurements. The chemical composition of $20 \mathrm{~nm}$ diameter aerosol performed during BEACHONRoMBAS was obtained by the Thermal Desorption Chemical
Ionization Mass Spectrometer (TDCIMS; Voisin et al., 2003; Smith et al., 2004). During non-PBE periods and during weak events, the TDCIMS measured the composition of bulk aerosol $(<1 \mu \mathrm{m})$, whereas during PBEs (such as 10 August) the instrument measured the composition of $20 \mathrm{~nm}$ diameter particles. The TDCIMS acquired data in "negative ion mode" using the reagent ion $\mathrm{O}_{2}-\left(\mathrm{H}_{2} \mathrm{O}\right) n$, where $n$ is in the range of $1-3$, which allows for the detection of inorganic and organic acids. Proton Transfer Reaction Quadrupole Mass Spectrometers (PTR-MS) measured ambient monoterpenes and MBO - the dominant emissions from ponderosa pine. We also use gas-phase measurements of $\mathrm{CO}, \mathrm{NO}_{\mathrm{x}}, \mathrm{SO}_{2}$ and $\mathrm{H}_{2} \mathrm{SO}_{4}$ meteorological measurements of wind speeds and direction (at $30 \mathrm{~m}$ height), and measurements of CCN concentrations. The latter measurements were mostly performed at $0.5 \% \mathrm{SS}$ with critical activation diameters less than $65 \mathrm{~nm}$, and included the corresponding derived hygroscopicity parameter, kappa, for sub-100 nm particles (Petters and Kreidenweis, 2007). Size-resolved CCN measurements were made with a differential mobility analyzer (DMA; TSI 3071) followed by a Droplet Measurement Technologies cloud condensation nuclei counter (DMT-CCNC) and a condensation particle counter (CPC; TSI 3010) (Levin et al., 2012, 2014). In this paper, the time is presented in Mountain Standard Time (MST).

We also calculate the condensation sink $\left(\mathrm{CS}\right.$, in $\mathrm{s}^{-1}$, Eq. 1), which is the rate that condensable inorganic and organic vapors condense onto preexisting aerosols.

$\mathrm{CS}=2 \pi D_{i} \sum_{j} d_{j} \beta_{m}\left(K_{n j}, \alpha\right) N_{j}$,

where $D_{i}$ is the gas-phase diffusion coefficient of condensable gas $i\left(\mathrm{~m}^{2} \mathrm{~s}^{-1}\right), N_{j}$ is the number concentrations $\left(\mathrm{m}^{-3}\right)$ of particle $j$ with diameter $d_{j}(\mathrm{~m}), \beta_{m}$ is the transitional correction for the condensational mass flux, and is a function of the Knudsen number $K_{n j}\left(=2 \lambda / d_{j}\right)$ and the mass accommodation coefficient $\alpha$ given by Fuchs and Sutugin (1971), with $\lambda=6.8 \times 10^{-8} \mathrm{~m}$ and $\alpha=0.1$ in this study. The formation rate ( $J$; see Eq. 2 below) and the growth rate are estimated from available measurements, starting at $4.4 \mathrm{~nm}$ diameter, and are used to constrain the WRF-Chem model. To determine the formation rate of $\sim 5 \mathrm{~nm}$ particles $\left(J_{5 \mathrm{~nm}}\right)$, we linearly fit the measured number concentrations of particles over the range of $4.4-6.25 \mathrm{~nm}$ diameter between the onset and the end of PBEs. The slope of the fitted line provides the measured formation rate $\left(J_{5 \mathrm{~nm}}\right)$ that is used to evaluate the model calculated formation rate for the model bin $3.98-6.31 \mathrm{~nm}$. A similar method is applied to derive the formation rates for particles between $39-65 \mathrm{~nm}\left(J_{50 \mathrm{~nm}}\right)$ and $101-162 \mathrm{~nm}\left(J_{130 \mathrm{~nm}}\right)$ in the measurements, and their model equivalent values based on model bin 40-63 nm and bin 100 $158 \mathrm{~nm}$, respectively. It should be noted that the formation rate calculated here is the net formation rate which includes loss rates. We use the number mean diameter (NMD) to calculate the growth rate of particles in both measurements and 

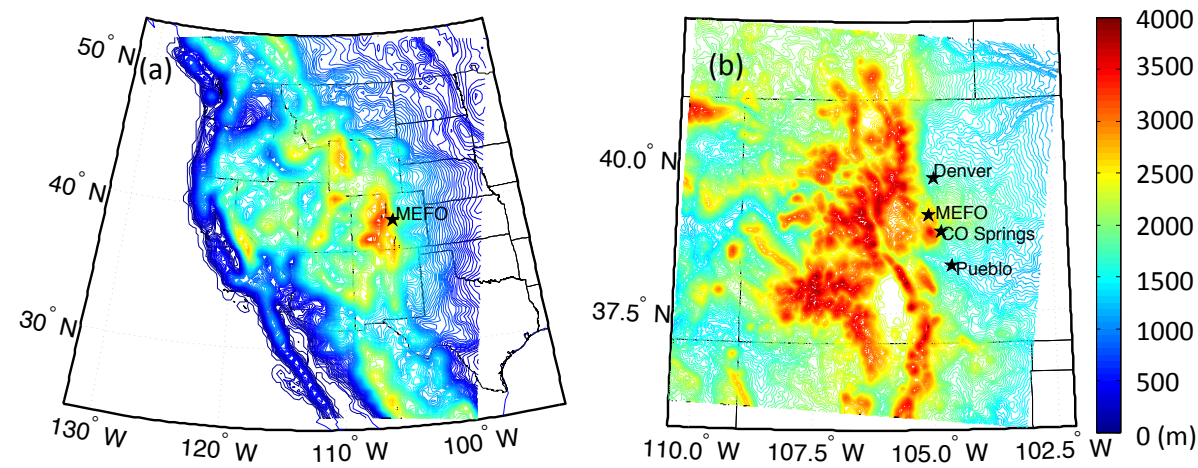

Figure 1. WRF-Chem domains. (a) Coarse domain covers the western US with $36 \times 36 \mathrm{~km}^{2}$ horizontal resolution; (b) nested domain covers Colorado with $4 \times 4 \mathrm{~km}^{2}$ resolution. Maps also show the topography, and the locations of the MEFO site, Denver, Colorado Springs, and Pueblo.

simulations. NMD was defined by Matsui et al. (2011) using the diameter (nm) and number concentration $\left(\mathrm{cm}^{-3}\right)$ in each size bin. We use a linear fit to the values of NMD for particles smaller than $30 \mathrm{~nm}$ during PBEs, and the slope of the fitted line is defined as the sub- $30 \mathrm{~nm}$ growth rate. Additionally, we calculate the hygroscopicity parameter, $\kappa$, by including all aerosol species present in the model for particles smaller than $100 \mathrm{~nm}$ (see Sect. 4.4).

\subsection{WRF-Chem simulations}

Version 3.4.1 of the Weather Research and Forecasting model with chemistry (WRF-Chem, Grell et al., 2005; Fast et al., 2006) was used with two nested domains over the continental United States. The grid resolution was $36 \mathrm{~km}$ for domain 1 and $4 \mathrm{~km}$ for domain 2 (Fig. 1). Two-way nesting was used between the domains. The WRF physics options chosen for our runs include the Monin-Obukhov scheme for the surface layer, the Yonsei University (YSU) scheme (Hong et al., 2006) for the planetary boundary layer, the Grell 3-D scheme (Grell and Devenyi, 2002) for the cumulus parameterization in the $36 \mathrm{~km}$ domain, the Lin et al. scheme for microphysics (Lin et al., 1983), a rapid radiative transfer model (Mlawer et al., 1997) for longwave radiation, and the Goddard scheme (Chou et al., 1998) for shortwave radiation. The nighttime minimum planetary boundary layer (PBL) height was set to $100 \mathrm{~m}$ in the YSU scheme based on previous studies (Choi et al., 2011) to eliminate overestimating nocturnal concentrations of primary species. The land cover treatment was updated with MODIS land use data. North American Regional Reanalysis (NARR) data were used for the initial and boundary conditions at a $3 \mathrm{~h}$ temporal resolution and $32 \mathrm{~km}$ spatial resolution. Two representative periods were selected for our study: 25-30 July and 9-15 August. The first $24 \mathrm{~h}$ of each run were used to initialize the model, but they were not used for comparisons. The meteorological outputs (such as wind field, PBL height, etc.) from WRF-Chem were used to drive a Lagrangian particle dispersion offline model (see Sect. 3.3) to estimate the arrival of anthropogenic plumes at the MEFO site.

The chemistry is simulated using the CBMz gas-phase mechanism (Zaveri and Peters, 1999) and MOSAIC aerosol package (Zaveri et al., 2008). Similar to Matsui et al. (2011), we have modified the MOSAIC aerosol package in WRFChem v3.4.1 to explicitly account for a wider range of aerosol sizes, i.e., 20 bins over the aerosol diameter range from $1 \mathrm{~nm}$ to $10 \mu \mathrm{m}$. The default eight bins over the range are from $40 \mathrm{~nm}$ to $10 \mu \mathrm{m}$. The default binary homogenous nucleation scheme (Wexler et al., 1994) is used above the PBL, and it has been replaced by the empirical AN scheme within the PBL. The number concentration of nucleated clusters based on the empirical AN scheme is given by Kulmala et al. (2006):

$J *=A \times\left[\mathrm{H}_{2} \mathrm{SO}_{4}\right]$,

where $J *$ is the formation rate of activated clusters at $1 \mathrm{~nm}$ $\left(\mathrm{cm}^{-3} \mathrm{~s}^{-1}\right), A\left(\mathrm{~s}^{-1}\right)$ is the rate coefficient, and $\left[\mathrm{H}_{2} \mathrm{SO}_{4}\right]$ is the number concentration of gas-phase sulfuric acid $\left(\mathrm{cm}^{-3}\right)$. Previous studies indicate a large uncertainty associated with calculations of $A$, which was found to range between $10^{-5} \mathrm{~s}^{-1}$ and $10^{-8} \mathrm{~s}^{-1}$ (Kuang et al., 2008). Here we estimate a representative value of $A$ at our site based on measured $\mathrm{H}_{2} \mathrm{SO}_{4}$ and number concentrations of ultrafine particles. The $\mathrm{H}_{2} \mathrm{SO}_{4}$ measurements are available from 9 to 26 August at MEFO and indicate that the average $\mathrm{H}_{2} \mathrm{SO}_{4}$ concentration is $\sim 2 \times 10^{6}$ molecules $\mathrm{cm}^{-3}$ during the late morning and early afternoon. During the campaign, the smallest particles with diameters of $\sim 5 \mathrm{~nm}$ were detected at the site on 28 July, and their number concentrations were used to determine the $5 \mathrm{~nm}$ aerosol formation rate $\left(J_{5 \mathrm{~nm}}=\sim 1 \mathrm{~cm}^{-3} \mathrm{~s}^{-1}\right.$ as shown in Table 1$)$. The rate coefficient $A$ of $2 \times 10^{-6} \mathrm{~s}^{-1}$ was derived from those measurements, and is used within WRF-Chem for the AN parameterization to introduce particles into the first model size bin $(1-4 \mathrm{~nm})$. We assume here that $J_{5 \mathrm{~nm}}$ is a representative value (the lower bound) of formation rate in the model 
Table 1. Characteristics of four representative PBE days at the MEFO site during the BEACHON-RoMBAS-2011 field campaign. Metrics are reported for observations and the WRF-Chem model simulations (Nucleation-bsoa).

\begin{tabular}{|c|c|c|c|c|c|c|c|c|c|}
\hline \multirow{2}{*}{$\begin{array}{l}\operatorname{PBE}(<30 \mathrm{~nm}) \\
\text { burst time (MST) }\end{array}$} & & \multirow[b]{2}{*}{ Growth rate ${ }^{\mathrm{a}}$} & \multirow[b]{2}{*}{$J_{5 \mathrm{~nm}}^{\mathrm{b}}$} & \multirow[b]{2}{*}{$J_{50 \mathrm{~nm}}$} & \multirow[b]{2}{*}{$J_{130 \mathrm{~nm}}$} & \multicolumn{2}{|c|}{$N_{4-40 \mathrm{~nm}}^{\mathrm{c}}$} & \multicolumn{2}{|c|}{$N_{40-100 \mathrm{~nm}}$} \\
\hline & & & & & & $\max$ & mean & $\max$ & mean \\
\hline \multirow{2}{*}{28 July $10: 20$} & Observation & 2.5 & 0.74 & 0.21 & 0.01 & 20540 & 16155 & 4.160 & 3.795 \\
\hline & Model & 3.0 & 1.09 & 0.20 & 0.02 & 34440 & 31515 & 5.389 & 5.357 \\
\hline \multirow{2}{*}{29 July 12:25 } & Observation & 2.0 & N/A & 0.24 & 0.02 & 31710 & 27865 & 13410 & 11622 \\
\hline & Model & 3.7 & N/A & 0.11 & 0.03 & 10650 & 9.551 & 5.342 & 5.282 \\
\hline \multirow{2}{*}{10 August 10:20 } & Observation & 2.5 & N/A & 0.08 & 0.01 & 22000 & 21470 & 6.562 & 5.336 \\
\hline & Model & N/A & N/A & 0.02 & 0.004 & 3.055 & 2.968 & 5.321 & 5.178 \\
\hline \multirow{2}{*}{ Average } & Observation & 2.3 & 0.74 & 0.18 & 0.013 & & & & \\
\hline & Model & 3.4 & 1.09 & 0.11 & 0.018 & & & & \\
\hline
\end{tabular}

\footnotetext{
a Growth rate of ultrafine particles from 4 to $40 \mathrm{~nm}$, in $\mathrm{nm} \mathrm{h}^{-1}$.

b $J$ : formation rate of small particles $\sim 5, \sim 50$ and $\sim 130 \mathrm{~nm}$, in $\mathrm{cm}^{-3} \mathrm{~s}^{-1}$.

${ }^{c}$ Number concentration of particles at $4-40$ and $40-100 \mathrm{~nm}$, in no. $/ \mathrm{cm}^{3}$. The mean values are averaged over a 2-hour time period following the peak of each PBE. In the model, values from particles in 3.98 to $39.8 \mathrm{~nm}$, and from particles in 39.8 to $100 \mathrm{~nm}$ are evaluated using observed $N_{4-40 \mathrm{~nm}}$ and $N_{40-100 \mathrm{~nm}}$. Here, we report particles from 4 to $40 \mathrm{~nm}$ instead of

4 to $30 \mathrm{~nm}$ in order to have a closer match with the corresponding bins in the simulations.
}

first bin, which is a reasonable assumption at high $\mathrm{H}_{2} \mathrm{SO}_{4}$ concentrations typically observed during PBE days (Kulmala et al., 2006). The derived value of $A$ is consistent with previous studies. For example, Sihto et al. (2006) reported $A=1.7 \times 10^{-6} \mathrm{~s}^{-1}$, whereas Matsui et al. (2011) used the value of $2 \times 10^{-7} \mathrm{~s}^{-1}$ which was a factor of 10 lower in order to compensate for a 10-fold overprediction of $\mathrm{H}_{2} \mathrm{SO}_{4}$ concentrations in WRF-Chem.

In addition, sulfuric acid concentrations could not be estimated for this study (Mikkonen et al., 2011; Petäjä et al., 2009) as $\mathrm{OH}$ measurements were not available during the considered time period. We attempted to more accurately simulate ultrafine particle growth by including the condensation of semi-volatile oxidation products of isoprene, $\alpha$ pinene and limonene onto preexisting particles. The default WRF-Chem model configuration only includes primary organic aerosols (Matsui et al., 2011), and accounting for the formation of secondary organic aerosols from biogenic precursors is important due to their abundance at this location. Simple molar yield calculations were used to estimate secondary organic aerosol formation, assuming $15 \%$ contribution for $\alpha$-pinene and limonene, and $4 \%$ for both isoprene (Liu et al., 2012) and MBO (Zhang et al., 2014). To reduce the computational costs, the condensed mass was distributed in proportion to the aerosol surface area in each size bin. This simplification is consistent with other studies (e.g., Spracklen et al., 2006; Reddington et al., 2011) and assumes that the first-generation oxidation products condense onto preexisting particles with zero equilibrium vapor pressure.

Initial and boundary conditions for chemical species were provided by the MOZART-4 global chemistry-transport model (Emmons et al., 2010). For emissions, the EPA Na- tional Emission Inventory 2005 was used for the anthropogenic sources. The number size distribution of primary aerosol emissions was assumed to be a lognormal distribution with a median diameter of $50 \mathrm{~nm}$ and a standard deviation (a sigma) of 2. The MEGAN online model was applied for biogenic emissions (Guenther et al., 2006). Wet scavenging and dry deposition of gases and aerosols were also considered. The aerosol direct and indirect effects on radiation and cloud microphysics were included according to Gustafson et al. (2007) and Chapman et al. (2009).

Table 2 summarizes the WRF-Chem simulations and their characteristics. The base run (Ref-8bins) is the original WRF-Chem model with eight diameter bins starting at $40 \mathrm{~nm}$. It includes the binary homogeneous nucleation parameterization in all vertical layers and does not account for the formation of secondary organic compounds (similar to Fast et al., 2009). The first test run (Nucleation-on) uses 20 bins and simulates the number concentration with the AN parameterization in the PBL and binary homogeneous nucleation parameterization above the PBL. The second test run (Nucleation-bsoa) is similar to Nucleation-on run, but in addition it includes the condensation of biogenic oxygenated semi-volatile organic compounds and their contribution to the growth of ultrafine particles. A final sensitivity run (Nucleation-off) uses 20 bins and includes the condensation of biogenic oxygenated semi-volatile organic compounds, but it does not include a nucleation parameterization (neither AN nor binary).

\subsection{The trajectory model}

To investigate the transport of anthropogenic air masses to the MEFO site during the field study period, the Lagrangian 
Table 2. Description of model simulations: AN is activation nucleation parameterization, and BHN is binary homogeneous nucleation parameterization, which is the default option in the WRF-Chem model (see Sects. 1 and 3.2).

\begin{tabular}{|c|c|c|c|c|}
\hline \multirow[t]{2}{*}{ Simulations } & \multirow[t]{2}{*}{ Number of aerosol bins } & \multicolumn{2}{|c|}{ Nucleation parameterizations } & \multirow{2}{*}{$\begin{array}{l}\text { Accounting for condensation } \\
\text { of biogenic VOCs }\end{array}$} \\
\hline & & Within PBL & Above PBL & \\
\hline Ref-8bins & 8 bins $(40 \mathrm{~nm}-10 \mu \mathrm{m})$ & \multicolumn{2}{|c|}{ BHN } & No \\
\hline Nucleation-on & 20 bins $(1 \mathrm{~nm}-10 \mu \mathrm{m})$ & AN & BHN & No \\
\hline Nucleation-bsoa & 20 bins $(1 \mathrm{~nm}-10 \mu \mathrm{m})$ & AN & BHN & Yes \\
\hline Nucleation-off & 20 bins $(1 \mathrm{~nm}-10 \mu \mathrm{m})$ & \multicolumn{2}{|c|}{ None } & Yes \\
\hline
\end{tabular}

particle dispersion model FLEXPART is used with WRF (WRF-FLEXPART, Stohl et al., 2005; Fast et al., 2006; Brioude et al., 2013). The wind field used to drive FLEXPART was a time-averaged wind predicted by the WRFChem $4 \mathrm{~km}$ simulations. We used the time-averaged wind to systematically decrease the uncertainty and bias in the trajectory calculations (Brioude et al., 2012). In WRFFLEXPART, the vertical diffusion coefficients were calculated based on the mixing heights and surface friction velocity from WRF-Chem. At the MEFO site, 10000 inert tracer particles are released every hour at a random height between 50 and $100 \mathrm{~m}$ above the ground. For each release, the backward trajectories are simulated for $48 \mathrm{~h}$. The total calculation time is 30 days from 27 July to 25 August 2013, and the number of releases is 720 . The hourly particle positions from the back-trajectories are gridded onto the $4 \times 4 \mathrm{~km}^{2}$ WRFChem domain to perform the residence time analysis. These gridded trajectories indicate the time that air masses spent in each grid cell before arriving at MEFO (de Foy et al., 2007, 2008), which illustrates the preferred wind directions and wind transport paths influencing the measurement site.

\section{Results and discussion}

\subsection{Characterization of PBE and non-PBE days}

The temporal evolution of aerosol number size distributions observed during the entire campaign is shown in Fig. 2a. To distinguish between PBE and non-PBE days, we calculate the ratio of the number concentrations of $4-30 \mathrm{~nm}$ particles $\left(N_{4-30 \mathrm{~nm}}\right)$ to the concentrations of 4-100 nm particles $\left(N_{4-100 \mathrm{~nm}}\right)$. When the ratio was larger than 0.5 (Jung et al., 2013) and the diurnal evolution of the aerosol number size distribution was characterized by a banana-shaped plot (Dal Maso et al., 2005), we classified that event as a PBE day. Using these criteria, we selected four representative PBEs (28, 29 July and 10, 13 August; see Fig. 2b), and three representative non-PBE days (14, 23, and 24 August). Figure $2 b$ shows the observed temporal evolution of $\mathrm{SO}_{2}$ mixing ratios and $N_{4-30 \mathrm{~nm}}$ at MEFO during the campaign. $N_{4-30 \mathrm{~nm}}$ was correlated with $\mathrm{SO}_{2}$ (Pearson correlation coefficient is 0.8 ), with $N_{4-30 n m}$ peak values that systematically coincided with high $\mathrm{SO}_{2}$ observed at the site. These results suggest that the inflow of anthropogenic pollutants impacts PBEs at the MEFO site, and that the PBEs are likely initiated by $\mathrm{SO}_{2}$ oxidation products. The daily cycle of monoterpenes (Fig. 2b) exhibits a more consistent day-to-day cycle with higher values at night and lower values at the midday. Isoprene concentrations were low at the site (Ortega et al., 2014) and are not shown here. A closer look at the diurnal evolution of the number size distribution during the PBE of 28 July (Fig. 3a, b) shows the typical banana-shaped growth of the number size distributions. The sharp increase in both $N_{4-30 \mathrm{~nm}}$ and $N_{30-100 \mathrm{~nm}}$ particles coincides with the shift in wind directions from westerly to northeasterly (from the Denver metropolitan area).

Observations of averaged diurnal profiles of $\mathrm{SO}_{2}, \mathrm{CO}$, monoterpenes, $N_{4-30 \mathrm{~nm}}, \mathrm{CCN}(0.5 \% \mathrm{SS})$, and number size distribution confirm the existence of large differences between PBE and non-PBE days (Fig. 4). Significantly higher mean values are observed during PBE days for both monoterpenes and $\mathrm{SO}_{2}$, and it is clear that $N_{4-30 \mathrm{~nm}}$ is dramatically starting midday during PBE days (Fig. 4c). CO levels are also higher during PBE days, which confirm that the MEFO site is influenced by the inflow of anthropogenic pollutants. Primary particles transported from the Front Range are not expected to significantly contribute to $N_{4-30 \mathrm{~nm}}$ concentrations because anthropogenic emissions typically generate larger particles (e.g., 30-40 nm; Brines et al., 2014). To appreciate how rapidly molecules condense onto preexisting aerosols, we also compare the condensation sink (CS) between PBE and non-PBE days. CS values range from $3 \times 10^{-3}$ to $7 \times 10^{-3} \mathrm{~s}^{-1}$ (Fig. $4 \mathrm{e}$ ), and are typical of forest areas (Dal Maso et al., 2002). Somewhat higher $(\sim 1.5$ times) CS values are found on PBE days just before the onset of PBEs (Figs. 4e and S2 in the Supplement), which indicates higher concentrations of preexisting particles on those days before the start of PBEs. During PBE days, the CS values decrease to their minimum around midday, which is generally the PBE onset time, and then progressively increase due to the growth of the ultrafine particles to larger sizes. There is also a large difference in size distributions between PBE and non-PBE days for particles smaller than $150 \mathrm{~nm}$ (Fig. 4f), which is typically the size range that encompasses the critical activation diameters for CCN (50-100 nm) (Petters and Kreidenweis, 2007). The peak of the number size distribution is shifted from $\sim 110 \mathrm{~nm}$ on non-PBE days to smaller 

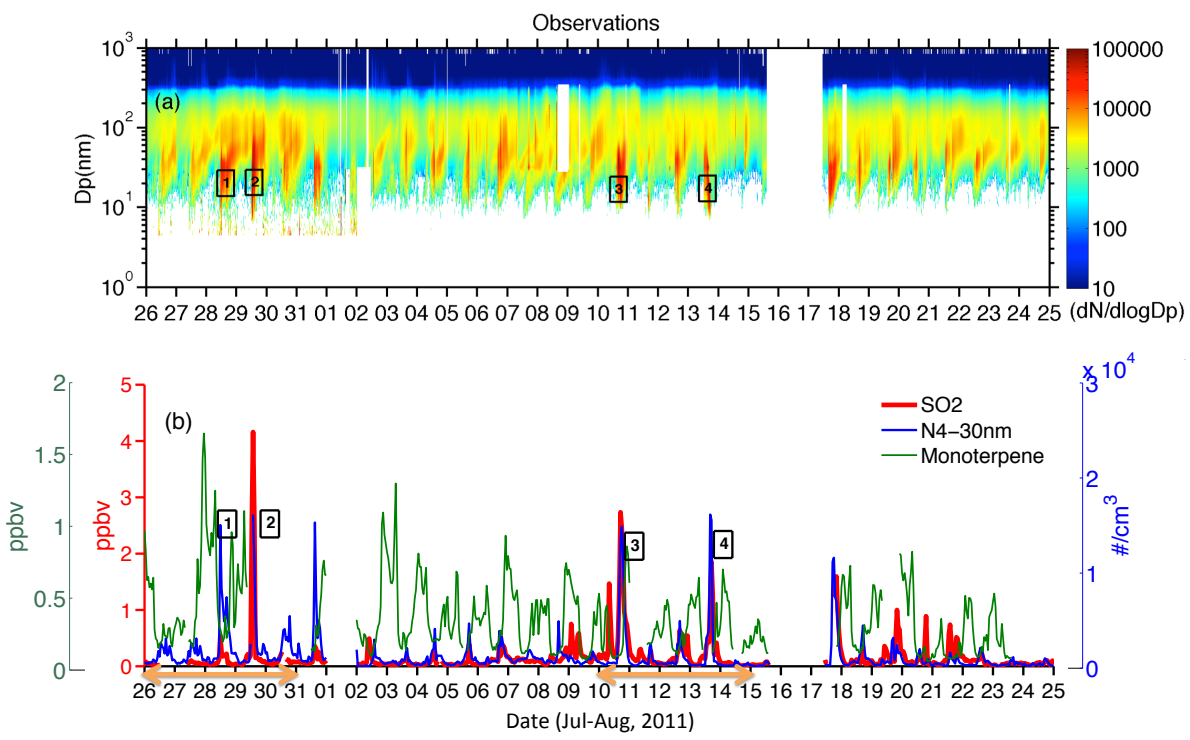

Figure 2. (a) Time series of number size distribution of submicron particles during BEACHON-RoMBAS. (b) Temporal variations in number concentrations of 4-30 nm diameter particles $\left(N_{4-30 \mathrm{~nm}}\right.$ ) (blue), $\mathrm{SO}_{2}$ (red), and monoterpene (green) mixing ratios during the campaign. The four PBEs are selected (28 and 29 July and 10 and 13 August) for comparisons with the model. The orange lines indicate the periods simulated with WRF-Chem.

diameters $\sim 30 \mathrm{~nm}$ on PBE days. Measured CCN $(0.5 \%$ SS) number concentrations at the surface are also up to a factor of 2 higher during afternoon hours on PBE days compared to non-PBE days (Fig. 3f). A sharp increase in $\mathrm{CCN}$ is observed in the afternoon, typically $3 \mathrm{~h}$ after the start of PBEs. It should be noted that only particles larger than $\sim 60 \mathrm{~nm}$ are likely to activate at $0.5 \%$ SS (Dusek et al., 2006). Given the observed growth rates of $2.3 \mathrm{~nm} \mathrm{~h}^{-1}$ (Table 1), it would take $>20 \mathrm{~h}$ for freshly nucleated particles to reach a diameter of $60 \mathrm{~nm}$. Therefore, the higher CCN concentrations on PBE days are likely the result of the enhanced growth of preexisting particles. Finally, the comparison of measured ambient $2 \mathrm{~m}$ temperatures (Fig. S1 in the Supplement, first panel) shows $1-2{ }^{\circ} \mathrm{C}$ cooler temperatures during PBE days.

Table 1 shows the observed and predicted formation and growth rates for $\sim 5, \sim 50$, and $\sim 130 \mathrm{~nm}$ diameter particles, and number concentrations of 4-40 nm $\left(N_{4-40 \mathrm{~nm}}\right)$ and $40-100 \mathrm{~nm}\left(N_{40-100 \mathrm{~nm}}\right)$ particles for PBEs that occurred at MEFO on 28 and 29 July, and 10 August. The PBEs at the MEFO site typically started around noon and early afternoon (10:20-15:00 MST, Table 1) following a shift in wind directions generally to the east (Fig. 5a). This late onset time was reported for other forest sites (Jung et al., 2013). $N_{4-40 \mathrm{~nm}}$ and $N_{40-100 \mathrm{~nm}}$ reported in Table 1 are calculated as average values over a 2-hour time period following the peak of each PBE. Here, we report particles from 4 to $40 \mathrm{~nm}$ instead of 4 to $30 \mathrm{~nm}$ in order to have a closer match with the corresponding bins in the simulations. The observed $N_{4-40 \mathrm{~nm}}$ averaged during the event varies from $\sim 16000$ to $\sim 28000 \mathrm{~cm}^{-3}$, and $N_{40-100 \mathrm{~nm}}$ from $\sim 4000$ to $12000 \mathrm{~cm}^{-3} . N_{4-40 \mathrm{~nm}}$ is 3 to 4 times higher compared to $N_{40-100 \mathrm{~nm}}$. The observed number size distribution during these PBE days (Fig. S4 in the Supplement) shows a relatively broad distribution similar to previous studies performed in an anthropogenically influenced forest (Jung et al., 2013). Figure S4 in the Supplement also shows the absence of particles smaller than $5 \mathrm{~nm}$. Especially in August (Fig. 8a), particles smaller than $10 \mathrm{~nm}$ were almost never observed suggesting that nucleation likely occurred in upwind areas or in the free troposphere, and that freshly nucleated particles grew for several hours before reaching the measurement site. It should be noted that the PBE episode of 13 August was very atypical showing an inverse bananashaped growth (Fig. 8a). The FLEXPART back-trajectories show that this "shrinkage" in the observed number size distribution could be related to the change in the air mass that is being sampled over the site during this event. The arrival of a polluted air mass from the Colorado Springs area during the afternoon (see Fig. S5 in the Supplement) is a likely reason for the appearance of smaller particles, which could have been nucleated slightly upwind of the measurement site.

For all PBEs, the average growth rate was estimated to be $2.3 \mathrm{~nm} \mathrm{~h}^{-1}$, and the average net rates of formation for $\sim 5 \mathrm{~nm}, \sim 5$ and $\sim 130 \mathrm{~nm}$ particles to $0.74 \mathrm{~cm}^{-3} \mathrm{~s}^{-1}$, $0.18 \mathrm{~cm}^{-3} \mathrm{~s}^{-1}$, and $0.013 \mathrm{~cm}^{-3} \mathrm{~s}^{-1}$, respectively. The values derived from these observations are consistent with previous results reported for other forested regions (Kuang et al., 2008; Westervelt et al., 2013). The comparisons between observations and simulations are discussed in Sect. 4.3. 

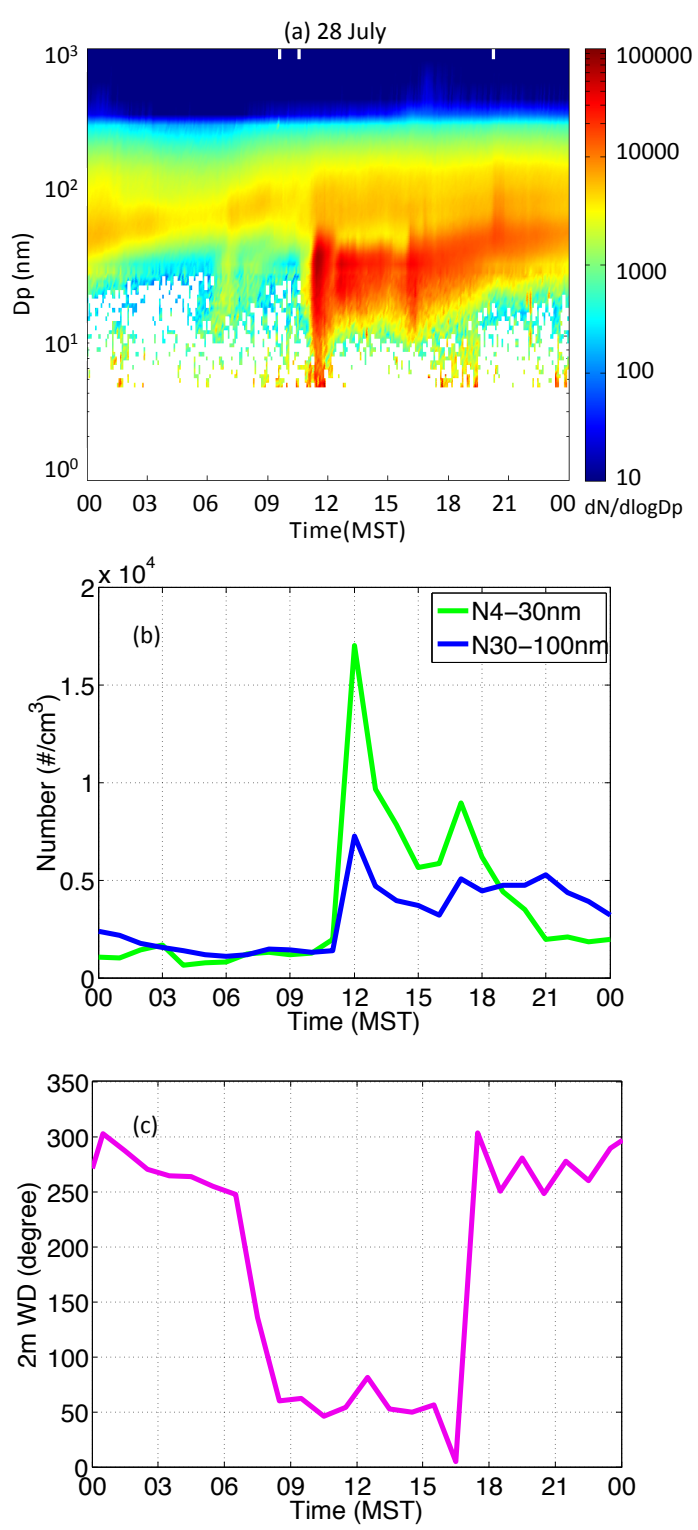

Figure 3. 28 July: (a) shows the diurnal cycle of the number size distributions. (b) shows the diurnal cycle of number concentrations for particles from 4 to $30 \mathrm{~nm}$ and 30 to $100 \mathrm{~nm}$. (c) shows the diurnal cycle of wind directions at $2 \mathrm{~m}$.

\subsection{Inflow of anthropogenic pollutants at MEFO}

To investigate the relationship between PBEs and the transport of anthropogenic pollutants to the site, we have analyzed the origin of the air masses arriving at the measurement site prior to PBEs. The wind roses measured at MEFO at a $30 \mathrm{~m}$ height show the variation of wind direction by time of day for PBE and non-PBE days (Fig. 5a, b). During PBE days, wind directions clearly show a shift from southwesterly in the early morning (06:00-09:00 MST) to easterly and then to southeasterly or northeasterly winds during the day (10:0017:00 MST). The dominant easterly wind component indi- cates influence from the Front Range urban areas, whereas on non-PBE days they are more consistently from the southwest. Because the measured near-surface winds at the site can be greatly influenced by local topography, we have performed the residence time analysis based on the FLEXPART back-trajectories to confirm the origin of the air masses for the PBE and non-PBE days. The right panels of Fig. 5a and $b$ show that on PBE days air masses at MEFO came from the Colorado Springs area, whereas on non-PBE days the air masses are principally from the west. The results suggest that elevated $\mathrm{SO}_{2}$ likely originated from industrial sources located in the Colorado Springs area. Consistent with measurements (Fig. 3), back-trajectory results emphasize the key role of anthropogenic pollutants in the occurrence of ultrafine particle events at the MEFO site.

The average time for the air mass to be transported to MEFO during PBE days was estimated to $\sim 4 \mathrm{~h}$ for air masses originating in Colorado Springs, and to $\sim 7 \mathrm{~h}$ for air masses from the Denver metropolitan area. Given the estimated transport time, and the estimated growth rates of $\sim 3 \mathrm{~nm} \mathrm{~h}^{-1}$, particles arriving from Denver would have grown by $\sim 20-30 \mathrm{~nm}$ during transportation time to the site, whereas particles arriving from Colorado Springs would have grown by $\sim 15 \mathrm{~nm}$. It should be noted that primary emitted particles in the model have sizes of $50 \mathrm{~nm}$, and would appear at the MEFO site as $70-80 \mathrm{~nm}$ particles if they originated from Denver, and as $\sim 65 \mathrm{~nm}$ particles if they originated from Colorado Springs. Therefore their contribution to sub- $40 \mathrm{~nm}$ particles predicted at the site during PBE days is unlikely. Only particles that nucleated over urban areas and smaller than $10 \mathrm{~nm}$ could contribute to the sub- $40 \mathrm{~nm}$ at MEFO if they were transported to the site. However, the nucleation events over urban areas are infrequent as the condensable gases preferably partition onto existing particles, which are typically abundant in urban areas.

\subsection{Evaluation of modeled PBEs}

The regional WRF-Chem model is used to simulate PBEs and analyze interactions between anthropogenic and biogenic air masses, as well as the potential influence of PBEs on $\mathrm{CCN}$ concentrations at the MEFO ground site. As mentioned in Sect. 3.2, the model includes both the AN parameterization that connects the anthropogenic $\mathrm{SO}_{2}$ emissions to nucleation, and the contributions of biogenic VOC emissions to the growth of ultrafine particles. Comparisons with measurements of $\mathrm{O}_{3}, \mathrm{CO}$ and $\mathrm{NO}_{2}$ (Fig. S6 in the Supplement) suggest that WRF-Chem generally captures their overall magnitudes and temporal variability during PBEs. Due to the complex mountain terrain, predicting the arrival of narrow pollution plumes at the site is challenging especially with the current model resolution of $4 \mathrm{~km}$. For instance on $29 \mathrm{July}$, WRF-Chem did not capture the observed $\mathrm{SO}_{2}$ plume at the site because of a west shift bias in the simulated wind direction. On 10 August, simulated $\mathrm{SO}_{2}$ was much lower than 

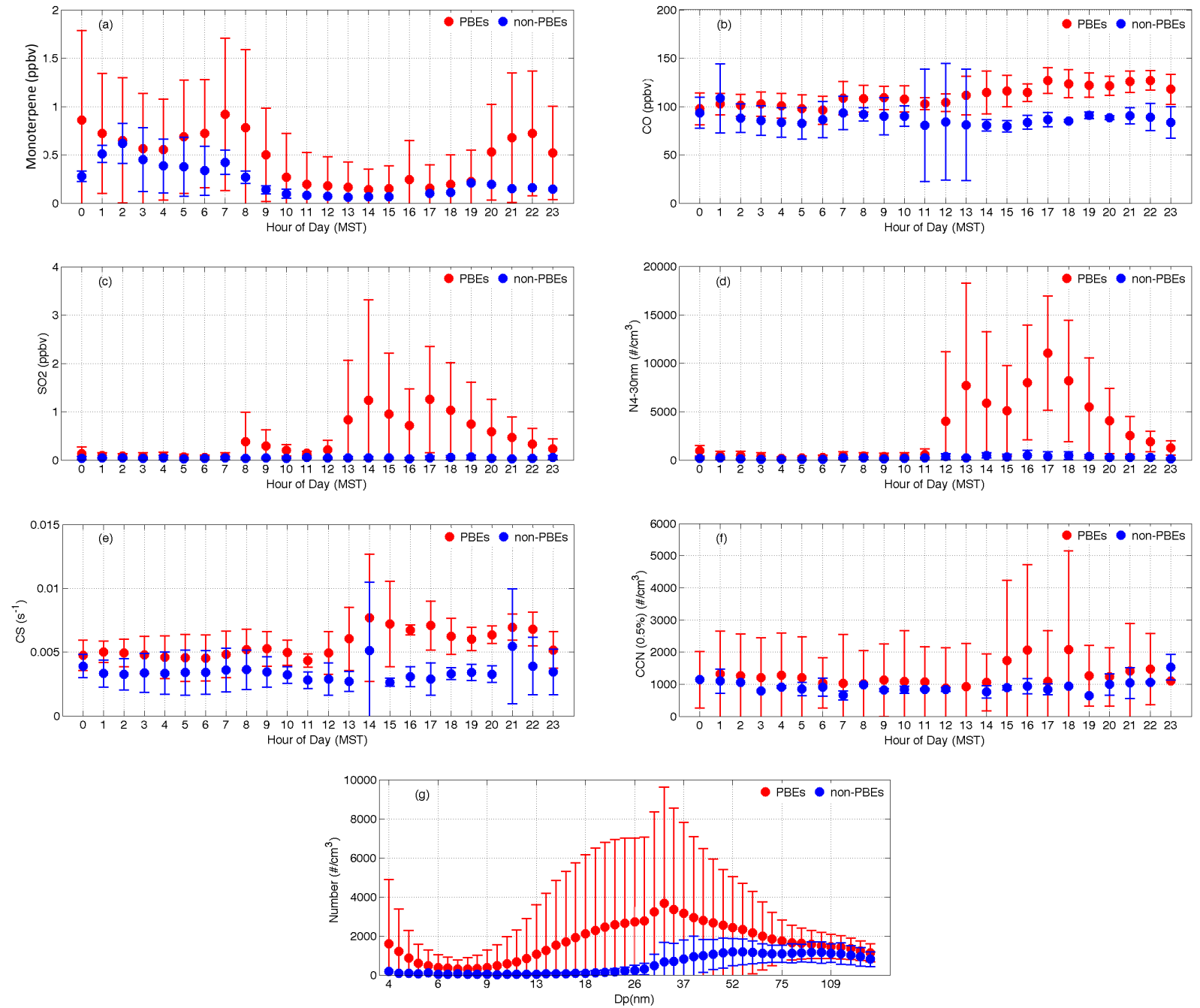

Figure 4. Comparison of measured parameters at the MEFO site during PBE and non-PBE days including hourly averaged diurnal profiles of (a) monoterpenes, (b) $\mathrm{CO}$, (c) $\mathrm{SO}_{2}$, (d) number concentrations of 4-30 nm diameter particles, (e) condensation sinks (CS, $\mathrm{s}^{-1}$ ), (f) $\mathrm{CCN}$ concentrations at $0.5 \%$ supersaturation, and (g) number size distribution (from 4.4 to $150 \mathrm{~nm}$ ). Error bars indicate $1 \sigma$ variability.

observations because of an excessively large westerly component in simulated winds. These biases in simulated $\mathrm{SO}_{2}$ influence the predicted levels of $\mathrm{H}_{2} \mathrm{SO}_{4}$ and lead to model underestimation of PBEs on those days (e.g., $N_{4-40 \mathrm{~nm}}$; Figs. 7 and 8).

Given the difficulty in predicting local meteorology, we examine (Fig. 6) the model's ability to reproduce the average features observed during PBE and non-PBE days. For that purpose, average diurnal profiles of observed and predicted parameters associated with number size distributions of sub-100 nm particles are examined. It is important to keep in mind that $N_{4-40 \mathrm{~nm}}$ is controlled by regional-scale nucleation and early particle growth, whereas $N_{40-100 \mathrm{~nm}}$ is also influenced by regional transport and anthropogenic emissions. The comparison of the number concentrations shows a noticeable improvement in model predictions when the Nucleation-bsoa run is used compared to the default WRF-
Chem configuration (Ref-8bins). The default configuration does not explicitly simulate $N_{4-40 \mathrm{~nm}}$, and greatly underestimates (up to a factor of 4) the $N_{40-100 \mathrm{~nm}}$ concentrations during both PBE and non-PBE days. The Nucleation-bsoa run captures well the increase in $N_{4-40 \mathrm{~nm}}$ during PBE days, although it has a tendency to nucleate some particles during non-PBE days as suggested by somewhat overpredicted $N_{4-40 \mathrm{~nm}}$ concentrations. This could be an artifact of the implementation of the AN parameterization in WRF-Chem which used measured formation rates of $5 \mathrm{~nm}$ particles to introduce nucleated particles into the model first bin, and could lead to an overprediction of freshly nucleated particles at low $\mathrm{H}_{2} \mathrm{SO}_{4}$ concentrations as discussed in Sect. 3.2. Simulation results (Fig. 6e) are clearly improved in terms of NMDs. During PBEs, the increase in number concentrations of ultrafine particles $\left(N_{4-40 \mathrm{~nm}}\right)$ leads to an NMD reduction at midday (12:00-18:00 MST) to values as low as $\sim 30 \mathrm{~nm}$, followed 
(a) PBE days

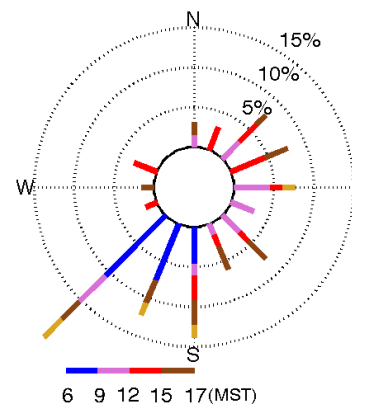

(b) non-PBE days

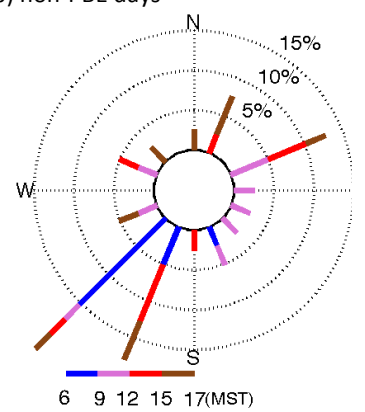

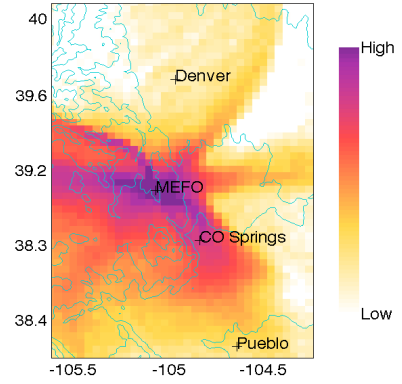

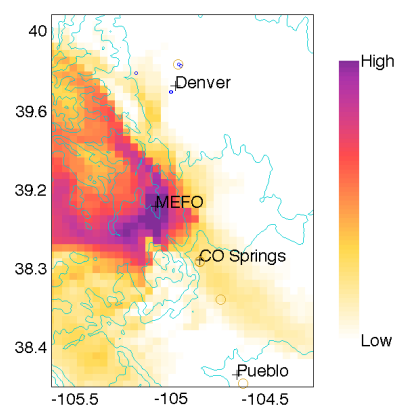

Figure 5. Wind fields for PBE days (a) and non-PBE days (b): left panels are wind roses of local wind variations at $30 \mathrm{~m}$ height plotted by hours of day at MEFO from 06:00 to 18:00 MS. Right panels are regional wind preferred directions corresponding to local wind roses respectively, based on WRF-FLEXPART analysis.

by an increase in NMD in the late afternoon due to the condensational growth. As expected the default Ref-8bins run did not capture the decrease in NMD during the early afternoon, caused by the appearance of freshly nucleated particles on PBE days. Observations (Fig. 3g) show that the peak of the number size distribution is shifted from $\sim 110 \mathrm{~nm}$ on nonPBE days to smaller diameters $\sim 30 \mathrm{~nm}$ on PBE days. This shift in NMDs was well predicted by the Nucleation-bsoa run (Fig. S7 in the Supplement). The comparison of modeled (Nucleation-bsoa) number size distributions between PBE and non-PBE days shows the same shift in the peak diameter from $\sim 100 \mathrm{~nm}$ on non-PBE days to $\sim 40 \mathrm{~nm}$ on PBE days. During non-PBE days, the Nucleation-bsoa run predicts slightly better the observed evolution of NMD than Ref8bins (Fig. 6f).

A more detailed day-to-day evaluation of predicted number concentrations and size distributions for sub- $100 \mathrm{~nm}$ particles is shown for 26-30 July (Fig. 7) and 10-14 August (Fig. 8). As mentioned in Sect. 4.1, during July PBEs had a more typical banana-shaped size distribution and particles down to $5 \mathrm{~nm}$ were observed, suggesting that new-particle formation likely occurred close to the measurement site. During this period, the updated WRF-Chem (Nucleation-bsoa run) was able to reproduce the banana shape of the number size distributions (Fig. 7a and b). The time series comparisons show that the Nucleation-bsoa simulation roughly cap- tures the variations in number concentrations of sub- $40 \mathrm{~nm}$ particles (Fig. 7c) and the diurnal evolution of the NMD (Fig. 7e). The model however has a tendency to overpredict the number concentrations of larger $N_{40-100 \mathrm{~nm}}$ particles and does not capture the sharp increase in those on 29 July. During August, PBEs were characterized by larger starting diameters $(>10 \mathrm{~nm})$ suggesting that new particle formation occurred upwind of the site or above the PBL, and that already somewhat grown particles were transported to the site. During this period, the WRF-Chem, Nucleation-bsoa run, initiated some local nucleation but did not grow these particles beyond $4 \mathrm{~nm}$ on 10, 11 and 14 August and not beyond $8 \mathrm{~nm}$ on 12 August (Fig. 8b). Model results suggest that the sub$100 \mathrm{~nm}$ particles that were both predicted and observed at the site on these days were not locally generated through nucleation. Sensitivity simulations were performed for the PBE day of 10 August to investigate the contribution of the transport of preexisting particles and of the above-PBL nucleation to predicted sub-100 $\mathrm{nm}$ particles (Fig. S8 in the Supplement). In the first sensitivity simulation, the nucleation parameterization was turned off in the model, and the resulting simulation showed very low number concentrations of sub$100 \mathrm{~nm}$ particles $\left(<500 \mathrm{~cm}^{-3}\right.$, Fig. $\left.8 \mathrm{~d}\right)$. In the second simulation, the binary nucleation parameterization was used above the PBL and no nucleation was used within the PBL. The results suggest that the above-PBL nucleation explained $90 \%$ 

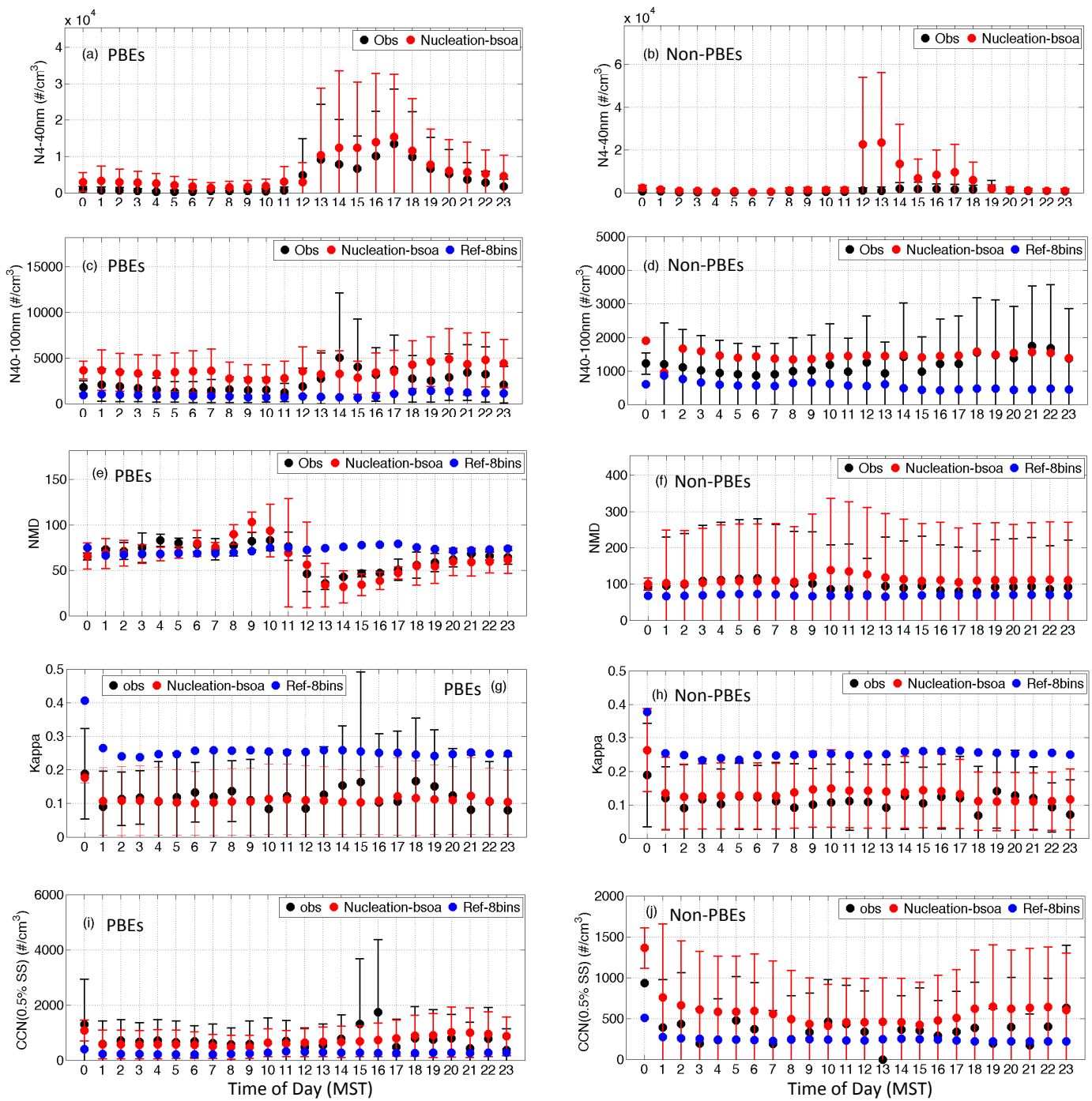

Figure 6. Comparison between measurements and simulations in diurnal profiles during PBE days (left column) and non-PBE days (right column). Black dots are observations, red dots are simulations from Nucleation-bsoa run, and blue dots are simulations from Ref-8bins run.

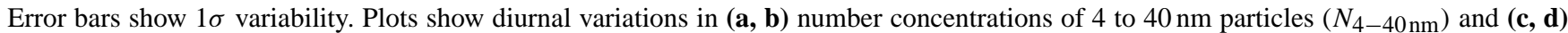
of 40 to $100 \mathrm{~nm}$ particles $\left(N_{40-100 \mathrm{~nm}}\right)$, diurnal profiles of $(\mathbf{e}, \mathbf{f})$ the number mean diameters (NMD), (g, h) kappa values, and (i, j) number concentrations of $\mathrm{CCN}$ at $0.5 \% \mathrm{SS}$.

of the ultrafine particles predicted at the surface on this particular day (Fig. S8b in the Supplement). The results from combined Nucleation-bsoa and sensitivity runs suggest that locally formed new particles were not able to grow to detectable sizes, and that free-troposphere nucleated particles could have been mixed downward into the boundary layer and contributed to observed $>10 \mathrm{~nm}$ particles. On $13 \mathrm{Au}-$ gust, the model starts nucleating particles locally but does not grow them to larger sizes. Larger particles are however predicted later in the afternoon (after 17:00 MST) and are likely due to changes in the air mass. Local wind roses and backtrajectories (Fig. S5 in the Supplement) both suggest a shift in wind direction from southwest to southeast during that afternoon, which advected polluted air from Colorado Springs to the measurement site as already discussed in Sect. 4.1. This change in the air mass could have brought already nucleated ultrafine particles to the site. As illustrated in Fig. 8c (no-nucleation run), the contribution of primary emitted particles to simulated sub- $40 \mathrm{~nm}$ is expected to be negligible as these particles are emitted into the larger size bins (centered at $50 \mathrm{~nm}$ diameter).

Modeled 4-40 $\mathrm{nm}$ diameter growth rates, and formation rates $\left(J_{5 \mathrm{~nm}}, J_{50 \mathrm{~nm}}, J_{130 \mathrm{~nm}}\right)$ are shown in Table 1 . In comparison with observations, we find that Nucleation-bsoa slightly overestimates the growth rates of sub- $40 \mathrm{~nm}$. In addition, the formation rates are underestimated for $50 \mathrm{~nm}$ particles $\left(J_{50 \mathrm{~nm}}\right)$ and overestimated for $100 \mathrm{~nm}$ particles $\left(J_{130 \mathrm{~nm}}\right)$ by the model. Predicted $N_{4-40 \mathrm{~nm}}$ and $N_{40-100}$ values are 

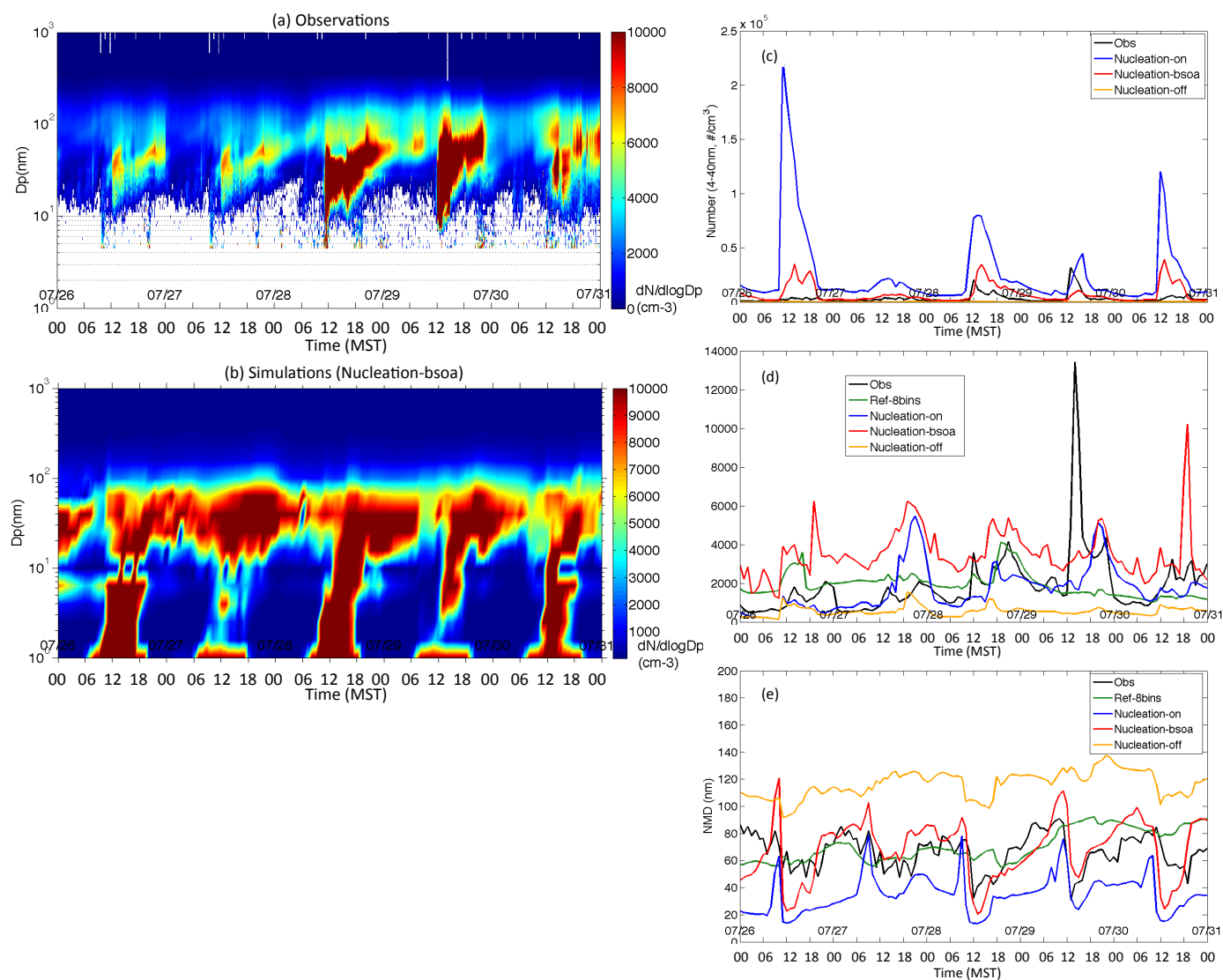

Figure 7. Temporal evolution of the (a) observed and (b) simulated (Nucleation-bsoa) number size distributions, during 26-30 July 2011. Time series of number concentrations of particles in size ranges of (c) 4-40 nm and (d) 40-100 nm, and (e) number mean diameter (NMD; see Eq. 1) as observed and predicted at the MEFO site. Measurements are indicated by the black line (OBS), base case is green, "Nucleation-on" is blue, "Nucleation-bsoa" is red, and "Nucleation-off" is orange, respectively (see Table 2 for the model run descriptions).

comparable to observations, with the exception of $N_{4-40 \mathrm{~nm}}$ on 29 July and 10 August, which is underestimated even in the Nucleation-bsoa run. These results indicate that the model configuration and spatial resolutions are not sufficiently accurate to capture all of the nucleation sources, and perhaps that the physical and chemical conditions encountered during nucleation events are not adequately represented by measurements performed at MEFO.

\subsection{Sensitivity to the treatment of nucleation}

There are large differences in simulation results in time series due to changes in the nucleation representation in WRFChem (Figs. 7c-e and 8c-e). As already shown, the default WRF-Chem simulation (Ref-8bins) does not explicitly simulate sub- $40 \mathrm{~nm}$ particles, and shows large biases in $N_{40-100 \mathrm{~nm}}$ concentrations (Figs. 7c, d, 8c, d) and NMD (Figs. 7e, 8e) during the campaign. The number size distributions are not captured during the PBE days suggesting that this default model version is not suitable for studying aerosol effect on $\mathrm{CCN}$ and clouds in forested environments. As expected, large differences with observations are found for the simulation that does not account for nucleation processes (Nucleation-off) with a factor of 5 underprediction of both $N_{4-40 \mathrm{~nm}}$ and $N_{40-100 \mathrm{~nm}}$ levels. Results from runs that include nucleation without condensational growth by organic vapors (Nucleation-on) generally overestimate $N_{4-40 \mathrm{~nm}}$ and underpredict the observed NMD by a factor of 2 suggesting that ultrafine particle growth is not captured by the model. The comparison between Nucleation-on and Nucleation-bsoa runs emphasizes the key role of biogenic VOC to the growth of freshly nucleated particles. The presence of biogenic secondary organic aerosol formation in the Nucleation-bsoa run results in a decrease of $N_{4-40 \mathrm{~nm}}$, by almost an order of magnitude, and an increase in $N_{40-100 \mathrm{~nm}}$ by a factor of 2 compared with Nucleation-on. Nucleation-bsoa

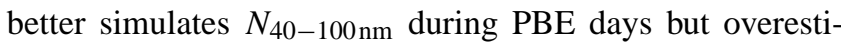
mates $N_{40-100 \mathrm{~nm}}$ during non-PBE days. Overall, our results suggest that the condensational growth from semi-volatile organic compounds plays an important role in PBEs over the Colorado Front Range, and that including the AN representation in the model considerably improves the simulation of PBEs. 

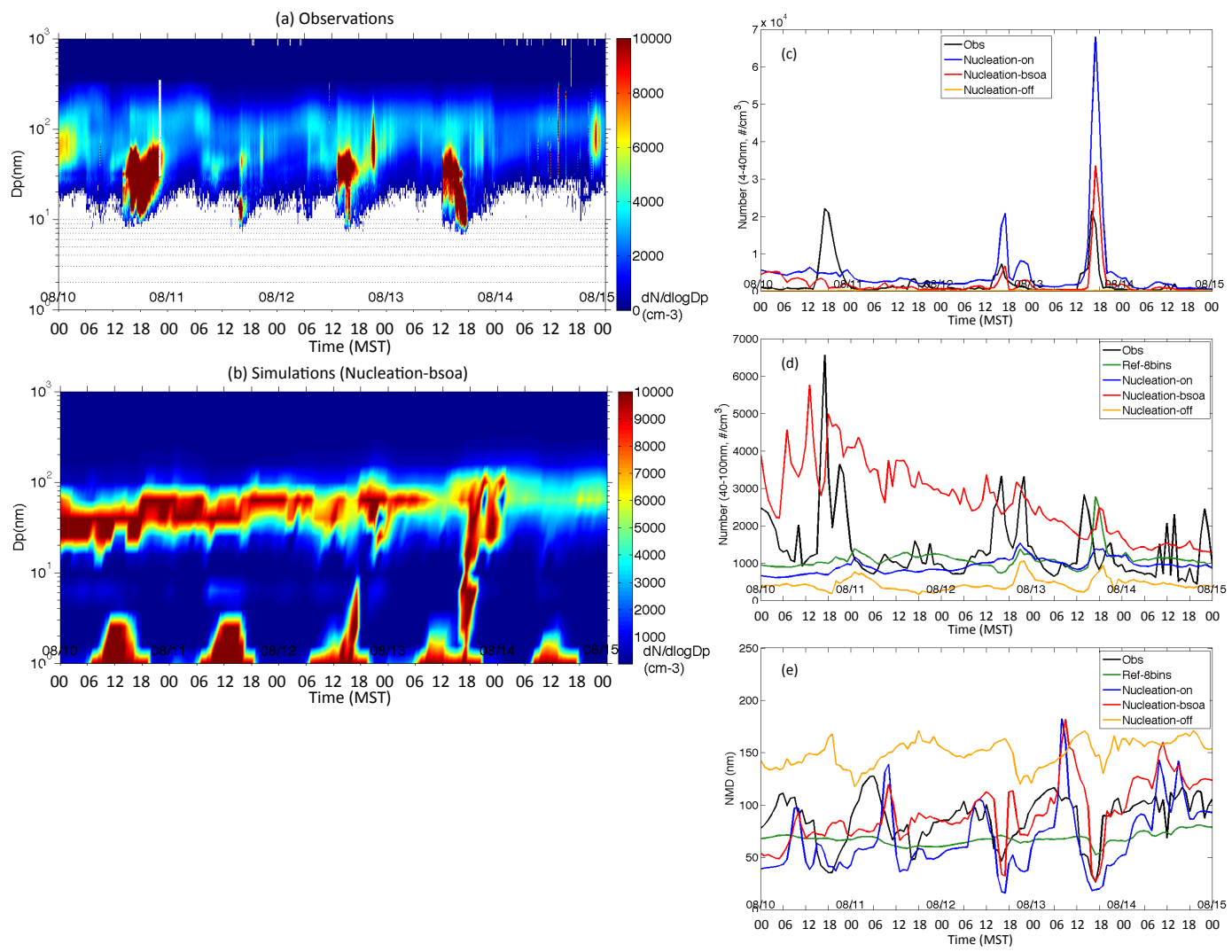

Figure 8. Similar to Fig. 7 but for the 10-14 August 2011 time period.

\subsection{Composition of ultrafine particles during PBEs and effects on $\mathrm{CCN}$}

TDCIMS measurements shown in Fig. 9a suggest that ultrafine aerosols observed at MEFO during PBE days are enriched in sulfate. The molar ratio of water-soluble species, which is defined as the abundance of a specific ion divided by the sum of all ion abundances, suggests that sub- $20 \mathrm{~nm}$ particles during the PBE of 10 August are made of $\sim 61 \%$ sulfate, $\sim 37 \%$ organics and $<1 \%$ nitrate. These values are similar to aerosol mass spectrometer measurements of bulk submicron $(<1 \mu \mathrm{m})$ aerosol composition averaged for 8,9 and 11 August during non-PBE days. The plot shows a clear difference in the relative abundance of sulfate during the PBE $(\sim 61 \%)$ vs. non-PBEs $(\sim 41 \%)$. However, this increase in sulfate cannot be attributed to the presence of PBEs, due to the difference in size distributions considered here $(20 \mathrm{~nm}$ vs. submicron).

Figure $9 \mathrm{~b}$ shows simulated mass fractions of sulfate and organics in $\sim 20 \mathrm{~nm}$ particles during PBE days (28, 29 July and 10 August) and non-PBE days (11 and 14 August). Results for PBEs show a factor of 2 increases in the relative contribution of sulfate to aerosol mass concentrations relative to non-PBE days. However, the relative fraction of sulfate in $\sim 20 \mathrm{~nm}$ particles during PBEs is larger in the mea- surements than in model predictions. This difference could result from the limitations in the detection of organic species by the TDCIMS instrument leading to an underprediction of the relative fraction of organics compared to sulfate. The fact that we are considering different days could also explain this discrepancy (i.e., measurements report values for 10 August, whereas the model results are averaged over several PBE days). Model predictions for 10 August (Fig. S8 in the Supplement) show a higher fraction of sulfate $(\sim 40 \%)$. In addition, model results for the Nucleation-bsoa simulation (Fig. S9 in the Supplement) indicate that organic aerosols account for 40 to $75 \%$ of the ultrafine $(4-20 \mathrm{~nm})$ particulate mass. The comparison with the Nucleation-off sensitivity simulation that has a factor of 3 lower amounts of sulfate, ammonium, and organics in the 4-20 nm range illustrates the importance of nucleation processes in predicting the ultrafine aerosol composition (see Fig. S9 in the Supplement).

Changes in submicron particle composition during PBEs can affect their hygroscopicity and, therefore, modify their ability to form CCN. Here we compare the measured and predicted volume-averaged hygroscopicity parameter (kappa) (Fig. 10). For calculations of kappa in WRF-Chem, we consider typical hygroscopicity values shown in parentheses (Chapman et al., 2009) for individual compounds including sulfate $(0.5)$, ammonium $(0.5)$, nitrate $(0.5)$, black carbon 

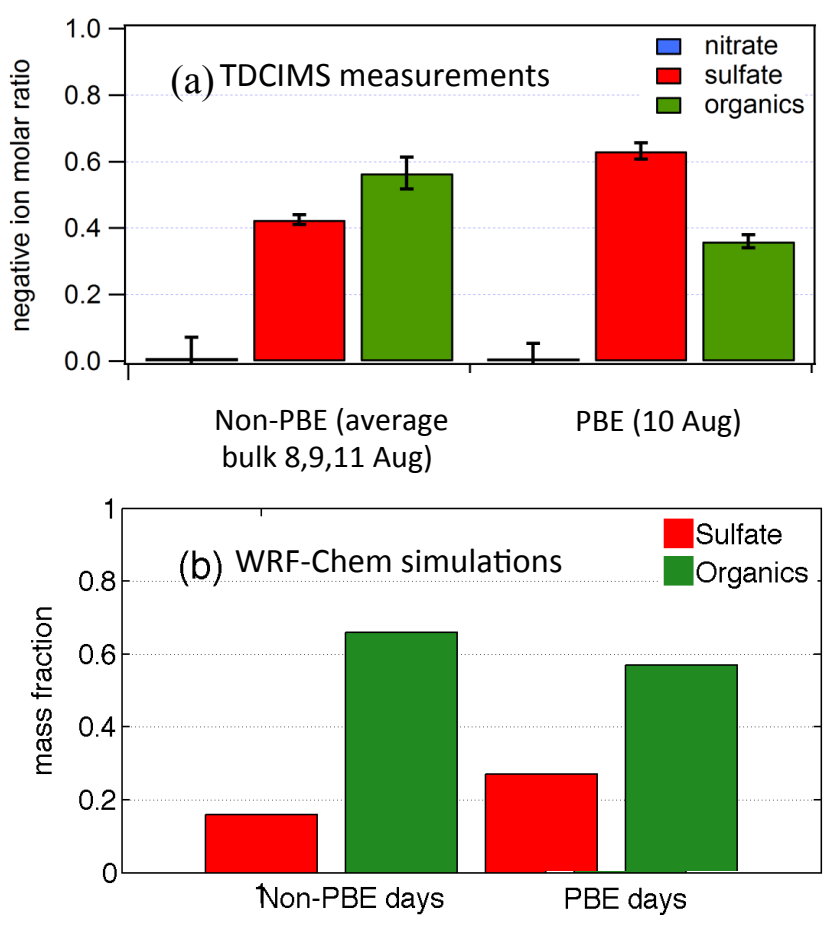

Figure 9. (a) TDCIMS measurements of negative ion molar ratios in bulk submicron aerosols during non-PBE days (8, 9, 11 August) and in $20 \mathrm{~nm}( \pm 0.5 \mathrm{~nm})$ particles during a PBE day (10 August). (b) Changes in simulated mass fractions of sulfate and organics in $\sim 20 \mathrm{~nm}$ particles between PBE days (28, 29 July and 10 August) and non-PBE days (11 and 14 August).

$\left(10^{-6}\right)$, organic compounds $(0.14)$, other inorganics (OIN, 0.14 ), sodium (1.16), and chloride (1.16). The calculated kappa value is the average of the hygroscopicity of individual species weighted by their respective volume concentrations for aerosol sizes below $100 \mathrm{~nm}$. For the Nucleationbsoa run, the model reasonably simulates the measured values of kappa. The Nucleation-bsoa simulation generally captures kappa variability in the time series (Fig. 10a, b) except for the lowest observed values during the nighttime that are overestimated by the model. We should note that 29 July has very high values of kappa ( $>0.3)$ indicative of an increased contribution of sulfate aerosols during the PBE. The model does not reproduce those high values, at least in part because the simulations do not capture the $\mathrm{SO}_{2}$ transport adequately on this day (see Sect. 4.3). The comparison of average diurnal profiles of observed and predicted kappa values during PBE and non-PBE days (Fig. $6 \mathrm{~g}-\mathrm{h}$ ) shows that the Nucleation-bsoa run improves simulations of hygroscopicity compared to the model default simulation Ref-8bins. In both the Nucleation-bsoa run and measurements, kappa values vary from $\sim 0.05$ to 0.2 during PBE and non-PBE days, and these values are typically a factor of 2 lower than the default model simulation (Ref-8bins) which does not account for the formation of secondary organic aerosols. Although
Nucleation-bsoa simulates an increase in the afternoon values of kappa, that increase is not as pronounced as in the observations (Fig. 6g).

The time series of measured and simulated $\mathrm{CCN}$ $(0.5 \% \mathrm{SS})$ number concentrations are shown in Fig. 10c-d. In this study, $\mathrm{CCN}$ concentrations are calculated at $0.5 \% \mathrm{SS}$ in the WRF-Chem model. As CCN measurements were mainly performed at high supersaturation (Sect. 3.1), here we compare model results with CCN observations at $0.5 \%$ SS. As previously mentioned (Sec. 4.1), only particles with diameters larger than $60 \mathrm{~nm}$ are likely to activate at $0.5 \%$ SS. The Nucleation-bsoa run reasonably simulates the CCN $(0.5 \%$ SS) concentrations in both time series (Fig. 10c, d) and diurnal profiles (Fig. 6i, j) except on 29 July as expected. Figure 6i shows that the Nucleation-bsoa run captures the magnitudes of CCN $(0.5 \%$ SS) during the daytime, with however a slight underestimation of the afternoon values during PBE days. The Nucleation-bsoa simulation reproduces more accurately $\mathrm{CCN}(0.5 \% \mathrm{SS})$ concentrations than the Ref-8bins run, especially during PBE days. This difference suggests that sub- $40 \mathrm{~nm}$ particles and their growth to larger sizes $(>60 \mathrm{~nm})$ that can activate at $0.5 \%$ SS significantly contribute to $\mathrm{CCN}$. The Nucleation-off simulation underestimates by a factor of 3 the $\mathrm{CCN}(0.5 \% \mathrm{SS})$ number concentration compared to Nucleation-bsoa (Fig. 10). This indicates that the ability of the modified WRF-Chem to predict PBEs is dependent on including both AN nucleation parameterization and secondary organic aerosol (SOA) formation. Comparing the results of Nucleation-bsoa with Nucleation-off during the two simulating periods, we find that the nucleation explains $67 \%$ of near-surface CCN $(0.5 \%$ SS) concentrations at the MEFO site. This is an extreme case; however, it illustrates that the accurate treatment of nucleation in 3-D models is important for predicting $\mathrm{CCN}(0.5 \% \mathrm{SS})$ concentrations and aerosol number concentration in general.

\section{Summary and conclusions}

Small particle burst events (PBEs), indicative of nucleationmode and Aitken-mode particles, were observed at the MEFO site during the 2011 BEACHON-RoMBAS field campaign. Four representative PBEs were studied that showed a rapid increase in the number of $4-30 \mathrm{~nm}$ diameter particles from midday to early afternoon in this region. Number concentrations of 4 to $40 \mathrm{~nm}$ particles ranged from $\sim 16000$ to $28000 \mathrm{~cm}^{-3}$, and 40 to $100 \mathrm{~nm}$ particles ranged from 4000 to $12000 \mathrm{~cm}^{-3}$. The average growth rate during PBEs of sub- $40 \mathrm{~nm}$ particles was $2.3 \mathrm{~nm} \mathrm{~h}^{-1}$, and the average formation rates of $\sim 5, \sim 50$, and $\sim 130 \mathrm{~nm}$ diameter particles during PBEs were $0.74 \mathrm{~cm}^{-3} \mathrm{~s}^{-1}, 0.18 \mathrm{~cm}^{-3} \mathrm{~s}^{-1}$, and $0.013 \mathrm{~cm}^{-3} \mathrm{~s}^{-1}$ respectively. The size distributions of ultrafine particles imply that non-local nucleation sources, including air masses originating above the PBL and upwind sources, impact MEFO. The diurnal profiles of $\mathrm{SO}_{2}$ 

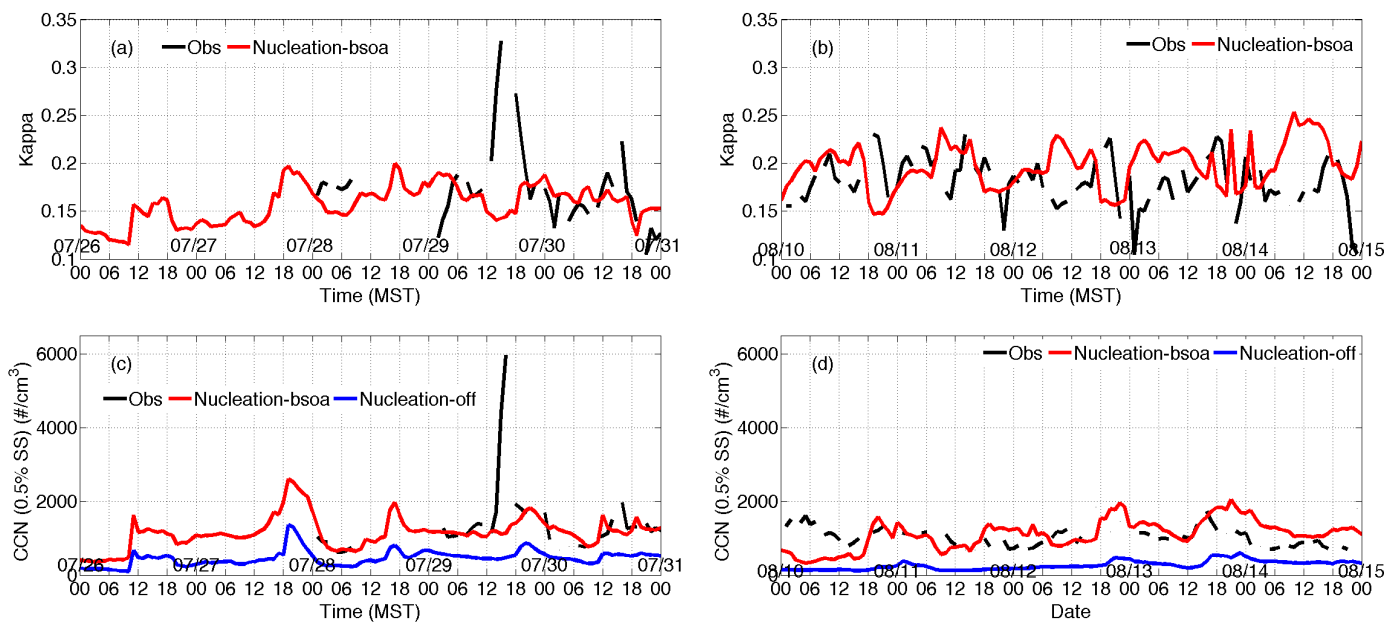

Figure 10. Observed and predicted (Nucleation-bsoa) (a, b) volume-averaged hygroscopicity (kappa) and (c, d) CCN concentrations at high supersaturation condition (0.5\% SS) from 26-30 July and 10-14 August 2011. The blue line shows the results without nucleation within PBL from "Nucleation-off" model run.

and monoterpene concentrations were investigated during $\mathrm{PBE}$ and non-PBE days. Considerable differences between PBEs and non-PBEs indicate that pollution plumes rich in $\mathrm{SO}_{2}$ combined with primary particles that were advected from the Colorado Front Range. Furthermore, enhanced biogenic monoterpenes concentrations significantly affect particle number concentrations and CCN during PBE days.

A modified version of the WRF-Chem model was applied to study PBEs during this campaign. The model was extended to include a parameterization of activation nucleation (AN) and the formation of SOA from biogenic and anthropogenic precursors. It also was used to simulate the corresponding volume-averaged hygroscopicity parameter (kappa) and CCN concentrations. Comparisons with the default WRF-Chem model (containing eight particle diameter bins and binary homogeneous nucleation parameterization) indicate that AN parameterization more accurately simulates PBEs in the $4-100 \mathrm{~nm}$ size range, including onset times, number concentrations and number mean diameters. The sensitivity simulations using the updated model without nucleation parameterization suggest that PBEs influence the composition of small particles. Furthermore, the updated WRF-Chem simulations were able to represent variations and magnitudes of kappa and number concentration of CCN ( $0.5 \%$ SS), suggesting that the model can be used to study the connection between new particle formation and cloud formation. Our results from the enhanced WRF-Chem model highlighted the important role of the mixing of urban and forest air masses in the formation of PBEs, and the value of the MEFO site in studying PBEs due to its location at the intersection of different air masses, and with help of improved treatment of PBEs in CCN simulations and future research for other representative forest sites adjacent to urban areas.

\section{The Supplement related to this article is available online at doi:10.5194/acp-14-11011-2014-supplement.}

Acknowledgements. The authors would like to acknowledge data contributions, interesting discussions and editing from Lisa Kaser (University of Innsbruck, Austria, and ASP postdoc at National Center for Atmospheric Research, NCAR), Ezra Levin (Colorado State University), David Gochis (National Center for Atmospheric Research, NCAR), Jerome Fast (Pacific Northwest National Laboratory, PNNL), and Christoph Knote (National Center for Atmospheric Research, NCAR). This research has been supported by the DOE DE-FG0208ER64627 grant, and NCAR which is operated by the University Corporation for Atmospheric Research on behalf of the National Science Foundation. Authors would like to thank in particular the generous support of the NCAR's Advanced Study Program/Graduate Visitor Program. P. Winkler acknowledges financial support from the Austrian Science Fund (FWF, project no. J3198-N21). J. N. Smith acknowledges support from the National Science Foundation (ATM-0919317) and US Department of Energy (DE-SC0006861).

Edited by: R. Holzinger

\section{References}

Adams, P. J. and Seinfeld, J. H.: Predicting global aerosol size distributions in general circulation models, J. Geophys. Res.-Atmos., 107, 4370, doi:10.1029/2001JD001010, 2002.

Brioude, J., Angevine, W. M., McKeen, S. A., and Hsie, E.-Y.: Numerical uncertainty at mesoscale in a Lagrangian model in complex terrain, Geosci. Model Dev., 5, 1127-1136, doi:10.5194/gmd-5-1127-2012, 2012.

Brioude, J., Arnold, D., Stohl, A., Cassiani, M., Morton, D., Seibert, P., Angevine, W., Evan, S., Dingwell, A., Fast, J. D., 
Easter, R. C., Pisso, I., Burkhart, J., and Wotawa, G.: The Lagrangian particle dispersion model FLEXPART-WRF version 3.1, Geosci. Model Dev., 6, 1889-1904, doi:10.5194/gmd-61889-2013, 2013.

Chapman, E. G., Gustafson Jr., W. I., Easter, R. C., Barnard, J. C., Ghan, S. J., Pekour, M. S., and Fast, J. D.: Coupling aerosolcloud-radiative processes in the WRF-Chem model: Investigating the radiative impact of elevated point sources, Atmos. Chem. Phys., 9, 945-964, doi:10.5194/acp-9-945-2009, 2009.

Choi, W., Faloona, I. C., McKay, M., Goldstein, A. H., and Baker, B.: Estimating the atmospheric boundary layer height over sloped, forested terrain from surface spectral analysis during BEARPEX, Atmos. Chem. Phys., 11, 6837-6853, doi:10.5194/acp-11-6837-2011, 2011.

Chou, M. D., Suarez, M. J., Ho, C. H., Yan, M. M. H., and Lee, K. T.: Parameterizations for cloud overlapping and shortwave single-scattering properties for use in general circulation and cloud ensemble models, J. Climate, 11, 202-214, 1998.

Dal Maso, M., Kulmala, M., Lehtinen, K. E. J., Makela, J. M., Aalto, P., and O'Dowd, C. D.: Condensation and coagulation sinks and formation of nucleation mode particles in coastal and boreal forest boundary layers, J. Geophys. Res.-Atmos., 107, 8097, doi:10.1029/2001JD001053, 2002.

Dal Maso, M., Kulmala, M., Riipinen, I., Wagner, R., Hussein, T., Aalto, P. P., and Lehtinen, K. E. J.: Formation and growth of fresh atmospheric aerosols: eight years of aerosol size distribution data from SMEAR II, Hyytiala, Finland, Boreal Environ. Res., 10, 323-336, 2005.

de Foy, B., Lei, W., Zavala, M., Volkamer, R., Samuelsson, J., Mellqvist, J., Galle, B., Martínez, A.-P., Grutter, M., Retama, A., and Molina, L. T.: Modelling constraints on the emission inventory and on vertical dispersion for $\mathrm{CO}$ and $\mathrm{SO}_{2}$ in the Mexico City Metropolitan Area using Solar FTIR and zenith sky UV spectroscopy, Atmos. Chem. Phys., 7, 781-801, doi:10.5194/acp-7781-2007, 2007.

de Foy, B., Fast, J. D., Paech, S. J., Phillips, D., Walters, J. T., Coulter, R. L., Martin, T. J., Pekour, M. S., Shaw, W. J., Kastendeuch, P. P., Marley, N. A., Retama, A., and Molina, L. T.: Basinscale wind transport during the MILAGRO field campaign and comparison to climatology using cluster analysis, Atmos. Chem. Phys., 8, 1209-1224, doi:10.5194/acp-8-1209-2008, 2008.

DiGangi, J. P., Henry, S. B., Kammrath, A., Boyle, E. S., Kaser, L., Schnitzhofer, R., Graus, M., Turnipseed, A., Park, J-H., Weber, R. J., Hornbrook, R. S., Cantrell, C. A., Maudlin III, R. L., Kim, S., Nakashima, Y., Wolfe, G. M., Kajii, Y., Apel, E.C., Goldstein, A. H., Guenther, A., Karl, T., Hansel, A., and Keutsch, F. N.: Observations of glyoxal and formaldehyde as metrics for the anthropogenic impact on rural photochemistry, Atmos. Chem. Phys., 12, 9529-9543, doi:10.5194/acp-12-9529-2012, 2012.

Dusek, U., Frank, G. P., Hildebrandt, L., Curtius, J., Schneider, J., Walter, S., Chand, D., Drewnick, F., Hings, S., Jung, D., Borrmann, S., Andreae, M. O.: Size Matters More Than Chemistry for Cloud-Nucleating Ability of Aerosol Particles, Science, 312, 1375-1378, doi:10.1126/science.1125261, 2006.

Dusek, U., Frank, G. P., Curtius, J., Drewnick, F., Schneider, J., Kurten, A., Rose, D., Andreae, M. O., Borrmann, S., and Poschl, U.: Enhanced organic mass fraction and decreased hygroscopic- ity of cloud condensation nuclei $(\mathrm{CCN})$ during new particle formation events, Geophys. Res. Lett., 37, L03804, doi:10.1029/2009GL040930, 2010.

Emmons, L. K., Apel, E. C., Lamarque, J.-F., Hess, P. G., Avery, M., Blake, D., Brune, W., Campos, T., Crawford, J., DeCarlo, P. F., Hall, S., Heikes, B., Holloway, J., Jimenez, J. L., Knapp, D. J., Kok, G., Mena-Carrasco, M., Olson, J., O'Sullivan, D., Sachse, G., Walega, J., Weibring, P., Weinheimer, A., and Wiedinmyer, C.: Impact of Mexico City emissions on regional air quality from MOZART-4 simulations, Atmos. Chem. Phys., 10, 6195-6212, doi:10.5194/acp-10-6195-2010, 2010.

Fast, J. D., Gustafson, W. I. J., Easter, R. C., Zaveri, R. A., Barnard, J. C., Chapman, E. G., Grell, G. A., and Peckham, S. E.: Evolution of ozone, particulates, and aerosol direct radiative forcing in the vicinity of Houston using a fully coupled meteorology-chemistry-aerosol model, J. Geophys. Res.-Atmos., 111, D21305, doi:10.1029/2005JD006721, 2006.

Fast, J., Aiken, A. C., Allan, J., Alexander, L., Campos, T., Canagaratna, M. R., Chapman, E., DeCarlo, P. F., de Foy, B., Gaffney, J., de Gouw, J., Doran, J. C., Emmons, L., Hodzic, A., Herndon, S. C., Huey, G., Jayne, J. T., Jimenez, J. L., Kleinman, L., Kuster, W., Marley, N., Russell, L., Ochoa, C., Onasch, T. B., Pekour, M., Song, C., Ulbrich, I. M., Warneke, C., Welsh-Bon, D., Wiedinmyer, C., Worsnop, D. R., Yu, X.-Y., and Zaveri, R.: Evaluating simulated primary anthropogenic and biomass burning organic aerosols during MILAGRO: implications for assessing treatments of secondary organic aerosols, Atmos. Chem. Phys., 9, 6191-6215, doi:10.5194/acp-9-6191-2009, 2009.

Fuchs, N. and A. Sutugin,: High-dispersed aerosols, in Topics in Current Aerosol Research,edited by: G. M. Hidy and J. R. Brock, Pergamon, Oxford, UK, 2, 1-60, 1971.

Fry, J. L., Draper, D. C., Zarzana, K. J., Campuzano-Jost, P., Day, D. A., Jimenez, J. L., Brown, S. S., Cohen, R. C., Kaser, L., Hansel, A., Cappellin, L., Karl, T., Hodzic Roux, A., Turnipseed, A., Cantrell, C., Lefer, B. L., and Grossberg, N.: Observations of gas- and aerosol-phase organic nitrates at BEACHON-RoMBAS 2011, Atmos. Chem. Phys., 13, 8585-8605, doi:10.5194/acp-138585-2013, 2013.

Grell, G. A. and Devenyi, D.: A generalized approach to parameterizing convection combining ensemble and data assimilation techniques, Geophys. Res. Lett., 29, 38-1-38-4, doi:10.1029/2002GL015311, 2002.

Grell, G. A., Peckham, S. E., Schmitz, R., McKeen, S. A., Frost, G., Skamarock, W. C., and Eder, B.: Fully coupled "online" chemistry within the WRF model, Atmos. Environ., 39, 6957-6975, 2005.

Guenther, A., Karl, T., Harley, P., Wiedinmyer, C., Palmer, P. I., and Geron, C.: Estimates of global terrestrial isoprene emissions using MEGAN (Model of Emissions of Gases and Aerosols from Nature), Atmos. Chem. Phys., 6, 3181-3210, doi:10.5194/acp-63181-2006, 2006.

Gustafson, W. I. J., Chapman, E. G., Ghan, S. J., Easter, R. C., and Fast, J. D.: Impact on modeled cloud characteristics due to simplified treatment of uniform cloud condensation nuclei during NEAQS 2004, Geophys. Res. Lett., 34, L19809, doi:10.1029/2007GL030021, 2007.

Hong, S. Y., Noh, Y., and Dudhia, J.: A new vertical diffusion package with an explicit treatment of entrainment processes, Mon. Weather Rev., 134, 2318-2341, 2006. 
Jung, J., Miyazaki, Y., and Kawamura, K.: Different characteristics of new particle formation between urban and deciduous forest sites in Northern Japan during the summers of 2010-2011, Atmos. Chem. Phys., 13, 51-68, doi:10.5194/acp-13-51-2013, 2013.

Kaser, L., Karl, T., Schnitzhofer, R., Graus, M., Herdlinger-Blatt, I. S., DiGangi, J. P., Sive, B., Turnipseed, A., Hornbrook, R. S., Zheng, W., Flocke, F. M., Guenther, A., Keutsch, F. N., Apel, E., and Hansel, A.: Comparison of different real time VOC measurement techniques in a ponderosa pine forest, Atmos. Chem. Phys., 13, 2893-2906, doi:10.5194/acp-13-2893-2013, 2013.

Kerminen, V. M. and Kulmala, M.: Analytical formulae connecting the "real" and the "apparent" nucleation rate and the nuclei number concentration for atmospheric nucleation events, J. Aerosol Sci., 33, 609-622, 2002.

Kerminen, V. M., Lihavainen, H., Komppula, M., Viisanen, Y., and Kulmala, M.: Direct observational evidence linking atmospheric aerosol formation and cloud droplet activation, Geophys. Res. Lett., 32, L14803, doi:10.1029/2005GL023130, 2005.

Kim, S., Karl, T., Guenther, A., Tyndall, G., Orlando, J., Harley, P., Rasmussen, R., and Apel, E.: Emissions and ambient distributions of Biogenic Volatile Organic Compounds (BVOC) in a ponderosa pine ecosystem: interpretation of PTR-MS mass spectra, Atmos. Chem. Phys., 10, 1759-1771, doi:10.5194/acp-101759-2010, 2010.

Kirkby, J., Curtius, J., Almeida, J., Dunne, E., Duplissy, J., Ehrhart, S., Franchin, A., Gagne, S., Ickes, L., Kurten, A., Kupc, A., Metzger, A., Riccobono, F., Rondo, L., Schobesberger, S., Tsagkogeorgas, G., Wimmer, D., Amorim, A., Bianchi, F., Breitenlechner, M., David, A., Dommen, J., Downard, A., Ehn, M., Flagan, R. C., Haider, S., Hansel, A., Hauser, D., Jud, W., Junninen, H., Kreissl, F., Kvashin, A., Laaksonen, A., Lehtipalo, K., Lima, J., Lovejoy, E. R., Makhmutov, V., Mathot, S., Mikkila, J., Minginette, P., Mogo, S., Nieminen, T., Onnela, A., Pereira, P., Petaja, T., Schnitzhofer, R., Seinfeld, J. H., Sipila, M., Stozhkov, Y., Stratmann, F., Tome, A., Vanhanen, J., Viisanen, Y., Vrtala, A., Wagner, P. E., Walther, H., Weingartner, E., Wex, H., Winkler, P. M., Carslaw, K. S., Worsnop, D. R., Baltensperger, U., and Kulmala, M.: Role of sulphuric acid, ammonia and galactic cosmic rays in atmospheric aerosol nucleation, Nature, 476, 429-U77, 2011.

Kuang, C., McMurry, P. H., McCormick, A. V., and Eisele, F. L.: Dependence of nucleation rates on sulfuric acid vapor concentration in diverse atmospheric locations, J. Geophys. Res.Atmos.,113, D10209, doi:10.1029/2007JD009253, 2008.

Kulmala, M.: How particles nucleate and grow, Science, 302, 10001001, 2003.

Kulmala, M., Hameri, K., Aalto, P. P., Makela, J. M., Pirjola, L., Nilsson, E. D., Buzorius, G., Rannik, U., Dal Maso, M., Seidl, W., Hoffman, T., Janson, R., Hansson, H. C., Viisanen, Y., Laaksonen, A., and O'Dowd, C. D.: Overview of the international project on biogenic aerosol formation in the boreal forest (BIOFOR), Tellus B, 53, 324-343, 2001.

Kulmala, M., Lehtinen, K. E. J., and Laaksonen, A.: Cluster activation theory as an explanation of the linear dependence between formation rate of $3 \mathrm{~nm}$ particles and sulphuric acid concentration, Atmos. Chem. Phys., 6, 787-793, doi:10.5194/acp-6-787-2006, 2006.

Kulmala, M., Kontkanen, J., Junninen, H., Lehtipalo, K., Manninen, H. E., Nieminen, T., Petaja, T., Sipila, M., Schobesberger,
S., Rantala, P., Franchin, A., Jokinen, T., Jarvinen, E., Aijala, M., Kangasluoma, J., Hakala, J., Aalto, P. P., Paasonen, P., Mikkila, J., Vanhanen, J., Aalto, J., Hakola, H., Makkonen, U., Ruuskanen, T., Mauldin, R. L., Duplissy, J., Vehkamaki, H., Back, J., Kortelainen, A., Riipinen, I., Kurten, T., Johnston, M. V., Smith, J. N., Ehn, M., Mentel, T. F., Lehtinen, K. E. J., Laaksonen, A., Kerminen, V. M., and Worsnop, D. R.: Direct Observations of Atmospheric Aerosol Nucleation, Science, 339, 943-946, 2013.

Laaksonen, A., Hamed, A., Joutsensaari, J., Hiltunen, L., Cavalli, F., Junkermann, W., Asmi, A., Fuzzi, S., and Facchini, M. C.: Cloud condensation nucleus production from nucleation events at a highly polluted region, Geophys. Res. Lett., 32, L06812, doi:10.1029/2004GL022092, 2005.

Levin, E. J. T., Prenni, A. J., Petters, M. D., Kreidenweis, S. M., Sullivan, R. C., Atwood, S. A., Ortega, J., DeMott, P. J., and Smith, J. N.: An annual cycle of size-resolved aerosol hygroscopicity at a forested site in Colorado, J. Geophys. Res.-Atmos., 117, D06201, doi:10.1029/2011JD016854, 2012.

Levin, E. J. T., Prenni, A. J., Palm, B. B., Day, D. A., CampuzanoJost, P., Winkler, P. M., Kreidenweis, S. M., DeMott, P. J., Jimenez, J. L., and Smith, J. N.: Size-resolved aerosol composition and its link to hygroscopicity at a forested site in Colorado, Atmos. Chem. Phys., 14, 2657-2667, doi:10.5194/acp-14-26572014, 2014.

Lin, Y., Langand Farley, R. D., and Orville, H. D.: Bulk parameterization of the snow field in a cloud model, J. Climate Appl. Meteorol., 22, 1065-1092, 1983.

Liu, X., Easter, R. C., Ghan, S. J., Zaveri, R., Rasch, P., Shi, X., Lamarque, J.-F., Gettelman, A., Morrison, H., Vitt, F., Conley, A., Park, S., Neale, R., Hannay, C., Ekman, A. M. L., Hess, P., Mahowald, N., Collins, W., Iacono, M. J., Bretherton, C. S., Flanner, M. G., and Mitchell, D.: Toward a minimal representation of aerosols in climate models: description and evaluation in the Community Atmosphere Model CAM5, Geosci. Model Dev., 5, 709-739, doi:10.5194/gmd-5-709-2012, 2012.

Luo, G. and Yu, F.: Simulation of particle formation and number concentration over the Eastern United States with the WRFChem + APM model, Atmos. Chem. Phys., 11, 11521-11533, doi:10.5194/acp-11-11521-2011, 2011.

Matsui, H., Koike, M., Kondo, Y., Takegawa, N., Wiedensohler, A., Fast, J. D., and Zaveri, R. A.: Impact of new particle formation on the concentrations of aerosols and cloud condensation nuclei around Beijing, J. Geophys. Res.-Atmos., 116, D19208, doi:10.1029/2011JD016025, 2011.

McFiggans, G., Artaxo, P., Baltensperger, U., Coe, H., Facchini, M. C., Feingold, G., Fuzzi, S., Gysel, M., Laaksonen, A., Lohmann, U., Mentel, T. F., Murphy, D. M., O’Dowd, C. D., Snider, J. R., and Weingartner, E.: The effect of physical and chemical aerosol properties on warm cloud droplet activation, Atmos. Chem. Phys., 6, 2593-2649, doi:10.5194/acp-6-2593-2006, 2006.

McMurry, P. H., Fink, M., Sakurai, H., Stolzenburg, M. R., Mauldin, R. L., Smith, J., Eisele, F., Moore, K., Sjostedt, S., Tanner, D., Huey, L. G., Nowak, J. B., Edgerton, E., and Voisin, D.: A criterion for new particle formation in the sulfur-rich Atlanta atmosphere, J. Geophys. Res.-Atmos., 110, 10, D22S02, doi:10.1029/2005JD005901, 2005.

Merikanto, J., Spracklen, D. V., Mann, G. W., Pickering, S. J., and Carslaw, K. S.: Impact of nucleation on global CCN, At- 
mos. Chem. Phys., 9, 8601-8616, doi:10.5194/acp-9-8601-2009, 2009.

Mikkonen, S., Romakkaniemi, S., Smith, J. N., Korhonen, H., Petäjä, T., Plass-Duelmer, C., Boy, M., McMurry, P. H., Lehtinen, K. E. J., Joutsensaari, J., Hamed, A., Mauldin III, R. L., Birmili, W., Spindler, G., Arnold, F., Kulmala, M., and Laaksonen, A.: A statistical proxy for sulphuric acid concentration, Atmos. Chem. Phys., 11, 11319-11334, doi:10.5194/acp-11-11319-2011, 2011.

Mlawer, E. J., Taubman, S. J., Brown, P. D., Iacono, M. J., and Clough, S. A.: Radiative transfer for inhomogeneous atmospheres: RRTM, a validated correlated-k model for the longwave, J. Geophys. Res.-Atmos., 102, 16663-16682, 1997.

O’Dowd, C. D., Hämeri, K., Mäkelä, J. M., Pirjola, L., Kulmala, M., Jennings, S. G., Berresheim, H., Hansson, H.-C., de Leeuw, G., Kunz, G. J., Allen, A. G., Hewitt, C. N., Jackson, A., Viisanen, Y., and Hoffmann, T.: A dedicated study of New Particle Formation and Fate in the Coastal Environment (PARFORCE): Overview of objectives and achievements, J. Geophys. Res., 107, 8108, doi:10.1029/2001JD000555, 2002.

Ortega, J., Turnipseed, A., Guenther, A. B., Karl, T. G., Day, D. A., Gochis, D., Huffman, J. A., Prenni, A. J., Levin, E. J. T., Kreidenweis, S. M., DeMott, P. J., Tobo, Y., Patton, E. G., Hodzic, A., Cui, Y. Y., Harley, P. C., Hornbrook, R. S., Apel, E. C., Monson, R. K., Eller, A. S. D., Greenberg, J. P., Barth, M. C., CampuzanoJost, P., Palm, B. B., Jimenez, J. L., Aiken, A. C., Dubey, M. K., Geron, C., Offenberg, J., Ryan, M. G., Fornwalt, P. J., Pryor, S. C., Keutsch, F. N., DiGangi, J. P., Chan, A. W. H., Goldstein, A. H., Wolfe, G. M., Kim, S., Kaser, L., Schnitzhofer, R., Hansel, A., Cantrell, C. A., Mauldin, R. L., and Smith, J. N.: Overview of the Manitou Experimental Forest Observatory: site description and selected science results from 2008 to 2013, Atmos. Chem. Phys., 14, 6345-6367, doi:10.5194/acp-14-6345-2014, 2014.

Petäjä, T., Mauldin, III, R. L., Kosciuch, E., McGrath, J., Nieminen, T., Paasonen, P., Boy, M., Adamov, A., Kotiaho, T., and Kulmala, M.: Sulfuric acid and $\mathrm{OH}$ concentrations in a boreal forest site, Atmos. Chem. Phys., 9, 7435-7448, doi:10.5194/acp9-7435-2009, 2009.

Petters, M. D. and Kreidenweis, S. M.: A single parameter representation of hygroscopic growth and cloud condensation nucleus activity, Atmos. Chem. Phys., 7, 1961-1971, doi:10.5194/acp-71961-2007, 2007.

Pierce, J. R. and Adams, P. J.: Uncertainty in global CCN concentrations from uncertain aerosol nucleation and primary emission rates, Atmos. Chem. Phys., 9, 1339-1356, doi:10.5194/acp-91339-2009, 2009.

Pierce, J. R., Riipinen, I., Kulmala, M., Ehn, M., Petäjä, T., Junninen, H., Worsnop, D. R., and Donahue, N. M.: Quantification of the volatility of secondary organic compounds in ultrafine particles during nucleation events, Atmos. Chem. Phys., 11, 90199036, doi:10.5194/acp-11-9019-2011, 2011.

Pierce, J. R., Leaitch, W. R., Liggio, J., Westervelt, D. M., Wainwright, C. D., Abbatt, J. P. D., Ahlm, L., Al-Basheer, W., Cziczo, D. J., Hayden, K. L., Lee, A. K. Y., Li, S.-M., Russell, L. M., Sjostedt, S. J., Strawbridge, K. B., Travis, M., Vlasenko, A., Wentzell, J. J. B., Wiebe, H. A., Wong, J. P. S., and Macdonald, A. M.: Nucleation and condensational growth to CCN sizes during a sustained pristine biogenic SOA event in a forested mountain valley, Atmos. Chem. Phys., 12, 3147-3163, doi:10.5194/acp-12-3147-2012, 2012.
Reddington, C. L., Carslaw, K. S., Spracklen, D. V., Frontoso, M. G., Collins, L., Merikanto, J., Minikin, A., Hamburger, T., Coe, H., Kulmala, M., Aalto, P., Flentje, H., Plass-Dülmer, C., Birmili, W., Wiedensohler, A., Wehner, B., Tuch, T., Sonntag, A., O’Dowd, C. D., Jennings, S. G., Dupuy, R., Baltensperger, U., Weingartner, E., Hansson, H.-C., Tunved, P., Laj, P., Sellegri, K., Boulon, J., Putaud, J.-P., Gruening, C., Swietlicki, E., Roldin, P., Henzing, J. S., Moerman, M., Mihalopoulos, N., Kouvarakis, G., Ždímal, V., Zíková, N., Marinoni, A., Bonasoni, P., and Duchi, R.: Primary versus secondary contributions to particle number concentrations in the European boundary layer, Atmos. Chem. Phys., 11, 12007-12036, doi:10.5194/acp-11-12007-2011, 2011.

Rosenfeld, D., Lohmann, U., Raga, G. B., O’Dowd, C. D., Kulmala, M., Fuzzi, S., Reissell, A., and Andreae, M. O.: Flood or drought: How do aerosols affect precipitation?, Science, 321, 1309- 313, 2008.

Sihto, S.-L., Kulmala, M., Kerminen, V.-M., Dal Maso, M., Petäjä, T., Riipinen, I., Korhonen, H., Arnold, F., Janson, R., Boy, M., Laaksonen, A., and Lehtinen, K. E. J.: Atmospheric sulphuric acid and aerosol formation: implications from atmospheric measurements for nucleation and early growth mechanisms, Atmos. Chem. Phys., 6, 4079-4091, doi:10.5194/acp-6-4079-2006, 2006.

Sipila, M., Berndt, T., Petaja, T., Brus, D., Vanhanen, J., Stratmann, F., Patokoski, J., Mauldin, Roy L., I., Hyvarinen, A.-P., Lihavainen, H., and Kulmala, M.: The Role of Sulfuric Acid in Atmospheric Nucleation, Science, 327, 1243-1246, 2010.

Smith, J. N., Moore, K. F., McMurry, P. H., and Eisele, F. L.: Atmospheric measurements of sub-20 nm diameter particle chemical composition by thermal desorption chemical ionization mass spectrometry, Aerosol Sci. Technol., 38, 100-110, 2004.

Somers, C. M., McCarry, B. E., Malek, F., and Quinn, J. S.: Reduction of particulate air pollution lowers the risk of heritable mutations in mice, Science, 304, 1008-1010, 2004.

Spracklen, D. V., Carslaw, K. S., Kulmala, M., Kerminen, V.-M., Mann, G. W., and Sihto, S.-L.: The contribution of boundary layer nucleation events to total particle concentrations on regional and global scales, Atmos. Chem. Phys., 6, 5631-5648, doi:10.5194/acp-6-5631-2006, 2006.

Stohl, A., Forster, C., Frank, A., Seibert, P., and Wotawa, G.: Technical note: The Lagrangian particle dispersion model FLEXPART version 6.2, Atmos. Chem. Phys., 5, 2461-2474, doi:10.5194/acp-5-2461-2005, 2005.

Voisin, D.,. Smith, J. N, Sakurai, H., McMurry P. H., and Eisele, F. L.: Thermal desorption chemical ionization mass spectrometer for ultrafine particle chemical composition, Aerosol Sci. Technol., 37, 471-475, 2003.

Westervelt, D. M., Pierce, J. R., Riipinen, I., Trivitayanurak, W., Hamed, A., Kulmala, M., Laaksonen, A., Decesari, S., and Adams, P. J.: Formation and growth of nucleated particles into cloud condensation nuclei: model-measurement comparison, Atmos. Chem. Phys., 13, 7645-7663, doi:10.5194/acp-13-76452013, 2013.

Wexler, A. S., Lurmann, F. W., and Seinfeld, J. H.: Modeling Urban and Regional Aerosols. I. Model Development, Atmos. Environ., 28, 531-546, 1994.

Young, L. H., Benson, D. R., Kameel, F. R., Pierce, J. R., Junninen, H., Kulmala, M., and Lee, S.-H.: Laboratory studies of $\mathrm{H}_{2} \mathrm{SO}_{4} / \mathrm{H}_{2} \mathrm{O}$ binary homogeneous nucleation from 
the $\mathrm{SO} 2+\mathrm{OH}$ reaction: evaluation of the experimental setup and preliminary results, Atmos. Chem. Phys., 8, 4997-5016, doi:10.5194/acp-8-4997-2008, 2008.

Zaveri, R. A. and Peters, L. K.: A new lumped structure photochemical mechanism for large-scale applications, J. Geophys. Res.Atmos., 104, 30387-30415, 1999.

Zaveri, R. A., Easter, R. C., Fast, J. D., and Peters, L. K.: Model for Simulating Aerosol Interactions and Chemistry (MOSAIC), J. Geophys. Res.-Atmos., 113, D13204, doi:10.1029/2007JD008782, 2008.
Zhang, H., Zhang, Z., Cui, T., Lin, Y.-H., Bhathela, N. A., Ortega, J., Worton, D. R., Goldstein, A. H., Guenther, A., Jimenez, J. L., Gold, A., and Surratt, J. D.: Secondary Organic Aerosol Formation via 2-Methyl-3-buten-2-ol Photo oxidation: Evidence of Acid-Catalyzed Reactive Uptake of Epoxides, Environ. Sci. Technol., 1, 242-247, 2014.

Zhang, R. Y., Suh, I., Zhao, J., Zhang, D., Fortner, E. C., Tie, X. X., Molina, L. T., and Molina, M. J.: Atmospheric new particle formation enhanced by organic acids, Science, 304, 1487-1490, 2004. 